\begin{tabular}{|lcl}
\hline REVISTA & NARRATIVAS \\
DA \\
FUNDARTE
\end{tabular}

\title{
PERSPECTIVAS ETNOGRÁFICAS E INFÂNCIAS INDÍGENAS: MODOS DE SER DAS CRIANÇAS ASURINÍ E BANIWA
}

\author{
Amanda Rodrigues Marqui \\ Xanda de Biase Miranda
}

DOI: $10.19179 / 2319-0868.789$

MARQUI, Amanda Rodrigues; MIRANDA, Xanda de Biase. Perspectivas etnográficas e infâncias indígenas: modos de ser das crianças Asuriní e Baniwa. Revista da FUNDARTE. Montenegro, p.0128, ano 20, no 42, julho/setembro de 2020.

Disponível em: http://.seer.fundarte.rs.gov.br/index.php/RevistadaFundarte/index> 30 de setembro de 2020 


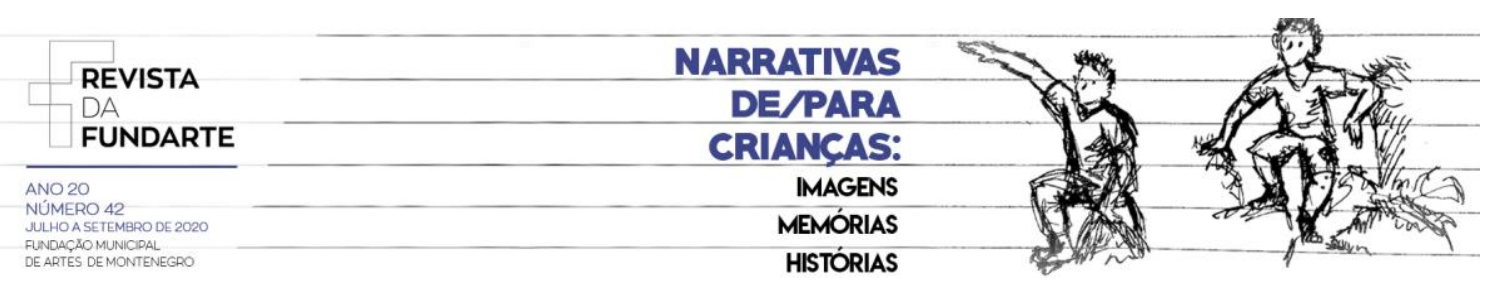

\title{
PERSPECTIVAS ETNOGRÁFICAS E INFÂNCIAS INDÍGENAS: MODOS DE SER DAS CRIANÇAS ASURINÍ E BANIWA
}

\author{
Amanda Rodrigues Marqui ${ }^{1}$ \\ Xanda de Biase Miranda²
}

\begin{abstract}
Resumo: Este artigo trata da experiência de pesquisa com crianças em dois contextos socioculturais distintos (MIRANDA, 2014; MARQUI, 2017), onde a observação etnográfica de questões semelhantes contribui para debates teóricos específicos. Diferentes modos de ser criança indígena, ser criança Asuriní ou Baniwa em suas formas particulares de "brincar-experimentar-trabalhar-descobriraprender" (LOPES DA SILVA, 2002) são observadas em espaços fisicamente similares, o rio e os pátios, mas ontológica e socialmente singulares. Partindo da ótica da chamada "antropologia da criança", que reitera o questionamento da naturalização da infância e reconhece a agência infantil na produção da cultura (COHN, 2005), as experiências dialogam com a noção de Pessoa (VIVEIROS DE CASTRO, DAMATTA; SEEGER, 1979), "arqui-categoria" que deixou sua marca na antropologia sul americana nas últimas décadas, e com questões colocadas pelo parentesco e organização social.
\end{abstract}

Palavras-chave: Crianças indígenas; Asuriní; Baniwa.

\section{ETHNOGRAPHIC PERSPECTIVES AND INDIGENOUS CHILDREN: WAYS OF BEING OF THE ASURINÍ AND BANIWA CHILDREN}

\begin{abstract}
This article deals with the research experience with children in different sociocultural contexts (MIRANDA, 2014; MARQUI, 2017), where an ethnographic observation of summative questions is carried out for specific theoretical debates. "Different modes of indigenous, Serian series" (LOPES DA SILVA, 2002) are observed in physically similar spaces, the river and the courtyards, but ontologically and socially unique. From the viewpoint of the so-called "anthropology of the child", which reiterates the questioning of childhood and childhood in the production of culture (COHN, 2005), as dialogical experiences with a notion of person (VIVEIROS DE CASTRO, DAMATTA; SEEGER, 1979), "arche-category" which left its mark on South American anthropology in the last decades, and with those placed by kinship and social organization.
\end{abstract}

Keywords : Indigenous children; Asuriní; Baniwa.

${ }^{1}$ Doutora em Antropologia Social pela Universidade Federal de São Carlos. Realizou pesquisas
etnográficas com as crianças Guarani Mbya no Pará sobre as perspectivas infantis a respeito dos
aprendizados escolares e com o povo Baniwa na Terra Indígena Alto Rio Negro, Amazonas, sobre as
relações entre infância, escola e religião. Foi pesquisadora do projeto "Observatório da Educação
Escolar Indígena - territórios Médio Xingu e Rio Negro" da CAPES/UFSCar. Atualmente é consultora
da UNESCO no Ministério da Educação-MEC para desenvolvimento de estudos técnicos sobre a
formação de professores indígenas.
2 Mestre em Antropologia Social pela Universidade Federal de São Carlos. Realizou pesquisas
etnográficas com as crianças Asuriní na Terra Indígena Koatinemo, Altamira. Foi pesquisadora do
projeto "Observatório da Educação Escolar Indígena - território Médio Xingu e Rio Negro"
(CAPES/UFSCar). É técnica em assuntos educacionais no Ministério da Educação- MEC.

MARQUI, Amanda Rodrigues; MIRANDA, Xanda de Biase. Perspectivas etnográficas e infâncias indígenas: modos de ser das crianças Asuriní e Baniwa. Revista da FUNDARTE. Montenegro, p.0128, ano 20, no 42, julho/setembro de 2020.

Disponível em: http://.seer.fundarte.rs.gov.br/index.php/RevistadaFundarte/index> 30 de setembro de 2020 


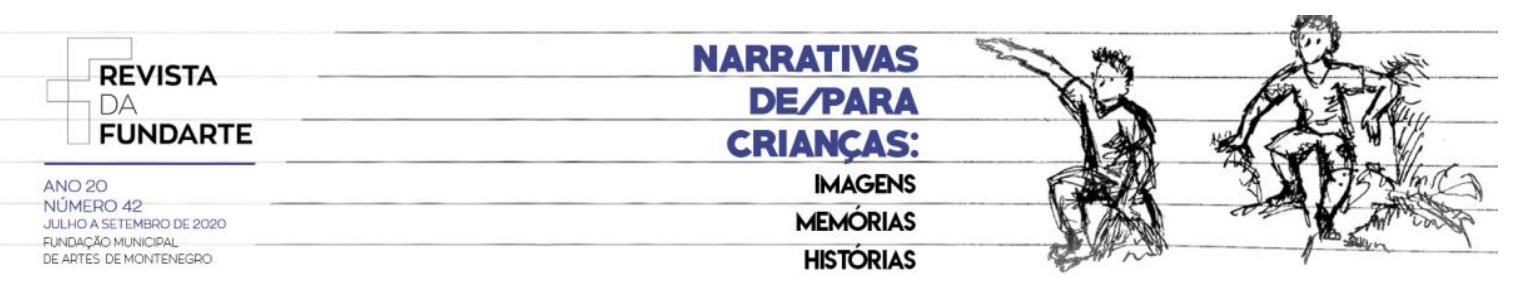

\title{
PERSPECTIVES ETHNOGRAPHIQUES ET ENFANTS AUTOCHTONES: MODES D'ÊTRE DES ENFANTS ASURINÍ ET BANIWA
}

\begin{abstract}
Résumé:
Cet article présente l'expérience de recherche avec des enfants dans des différents contextes socioculturels (MIRANDA, 2014; MARQUI, 2017), où l'observation ethnographique des questions similaires contribue pour des débats théoriques spécifiques. Ils sont observés des différents manières d'être indigènes (LOPES DA SILVA, 2002) dans des espaces physiquement similaires, le fleuve et les cours, mais uniques sur le plan ontologique et social. Sur le point de vue de "l'anthropologie de l'enfant" qui remet en cause la naturalisation de l'enfance et qui reconnaît l'agence infantile dans la production de la culture (COHN, 2005), les expériences dialoguent avec la notion de Personne (VIVEIROS DE CASTRO, DAMATTA; SEEGER, 1979), "archi-catégorie" qui a marqué l'anthropologie sud-américaine au cours des dernières décennies, ainsi que celles de la parenté et de l'organisation sociale.
\end{abstract}

Mots-clés: Enfant Indígene; Asurini; Baniwa.

\section{Introdução}

Este artigo trata da experiência de pesquisa com crianças em dois contextos socioculturais distintos (MIRANDA 2014; MARQUI, 2017) ${ }^{3}$, onde a observação etnográfica de questões semelhantes contribui para debates teóricos específicos. Diferentes modos de ser criança indígena, ser criança Asuriní ou Baniwa em suas formas particulares de "brincar-experimentar-trabalhar-descobrir-aprender" (LOPES DA SILVA 2002, p.46), são observadas em espaços fisicamente similares, o rio e os pátios, mas ontológica e socialmente singulares. Partindo da ótica da chamada "antropologia da criança", que reitera o questionamento da naturalização da infância e reconhece a agência infantil na produção da cultura (COHN, 2005), as experiências dialogam com a noção de Pessoa (VIVEIROS DE CASTRO, DAMATTA; SEEGER, 1979), “arqui-categoria” que deixou sua marca na antropologia sul americana nas últimas décadas, e com questões colocadas pelo parentesco e organização social.

\footnotetext{
${ }^{3}$ Sob a orientação da Profa ${ }^{2} r^{a}$ Clarice Cohn, as pesquisas foram financiadas pela Coordenação de Aperfeiçoamento de Pessoal de Nível Superior-CAPES, por meio do projeto "Observatório da Educação Escolar Indígena - territórios Médio Xingu e Rio Negro", na Universidade Federal de São Carlos, SP, no período de 2010 a 2015.
}

MARQUI, Amanda Rodrigues; MIRANDA, Xanda de Biase. Perspectivas etnográficas e infâncias indígenas: modos de ser das crianças Asuriní e Baniwa. Revista da FUNDARTE. Montenegro, p.0128, ano 20, no 42, julho/setembro de 2020.

Disponível em: http://.seer.fundarte.rs.gov.br/index.php/RevistadaFundarte/index> 30 de setembro de 2020 


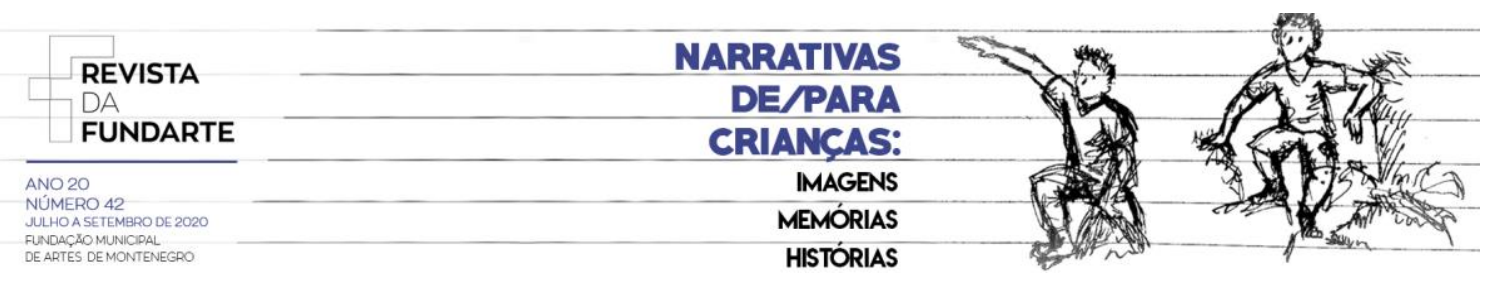

A experiência relatada por Miranda (2014) trata da observação de crianças Asuriní, povo do tronco linguístico Tupi. O trabalho de campo foi realizado em 2011, período em que os Asuriní se constituíam em uma população de 161 pessoas integralmente fixada na Terra Indígena Koatinemo, que ocupa 388 mil hectares da margem direita do rio Xingu, Pará. Berta Ribeiro (1982) estima uma população de cerca de 150 indivíduos na década de 30, que decresceu drasticamente após o contato no início da década de 70, chegando a apenas 52 indivíduos em 1982 (MÜLLER, 1990, p. 45). A experiência registrada por Marqui (2017) trata das relações entre infância, escola e religião dos Baniwa da região do médio rio Içana. Os Baniwa, um povo do tronco linguístico Aruak do noroeste amazônico, vive em comunidades localizadas na bacia hidrográfica do Içana, no rio Negro/Guainía ${ }^{4}$ e nos municípios de São Gabriel da Cachoeira, Santa Isabel e Barcelos no Amazonas, a estimativa da população total é de aproximadamente sete mil indivíduos (SIASI/SESAI 2014). A Terra Indígena Alto Rio Negro $^{5}$ abrange uma extensão territorial de aproximadamente de 80 mil quilômetros, onde vivem mais de 20 povos indígenas de três troncos linguísticos: Tukano, Aruak e Maku. A pesquisa de campo foi realizada em 2012 na comunidade de Vista Alegre localizada na margem esquerda do rio Cuiarí, um afluente do rio Içana, onde residiam aproximadamente 180 pessoas.

As etnografias destacam especificidades nos modos de se conceber crianças e fabricar corpos, na apropriação cotidiana dos lugares pelas crianças e nos regimes de conhecimento implicados nestes processos, mas convergem no que diz respeito ao rendimento da observação atenta da mobilidade e espacialidade para aprofundamento da compreensão do universo infantil e suas interlocuções com os debates dados pelo campo teórico (COHN, 2005; 2013). Sendo assim, pretende-se neste artigo revisar algumas questões desenvolvidas nas pesquisas etnográficas de

\footnotetext{
${ }^{4}$ Designação do rio Negro na Colômbia e na Venezuela.

5 Decreto de Homologação de 14 de abril de 1998, que demarca a TI Alto Rio Negro localizada nos municípios de São Gabriel da Cachoeira e Japurá no estado do Amazonas.
}

MARQUI, Amanda Rodrigues; MIRANDA, Xanda de Biase. Perspectivas etnográficas e infâncias indígenas: modos de ser das crianças Asuriní e Baniwa. Revista da FUNDARTE. Montenegro, p.0128, ano 20, no 42, julho/setembro de 2020.

Disponível em: http://.seer.fundarte.rs.gov.br/index.php/RevistadaFundarte/index> 30 de setembro de 2020 


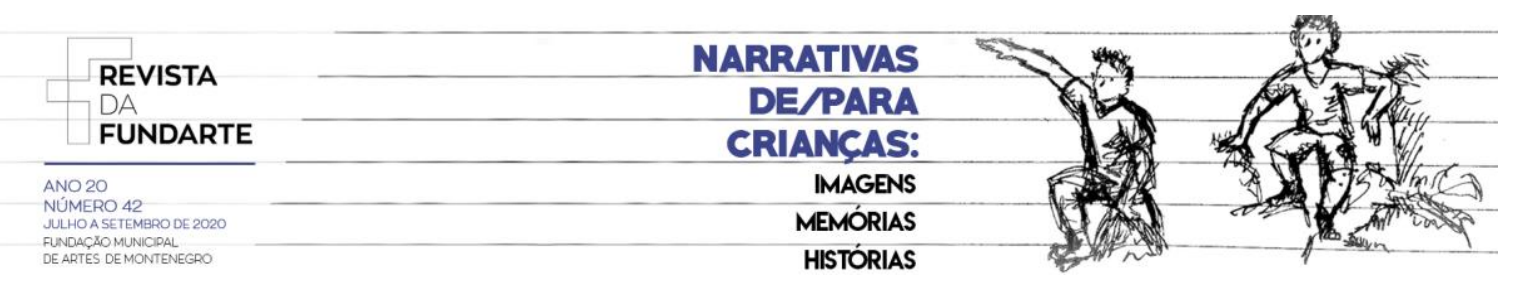

Miranda (2014) e Marqui (2017) para elaborar narrativas sobre e com crianças Asuriní e Baniwa.

\section{Sobre a água e os corpos}

\section{As crianças Asuriní}

A couvade Asuriní poderia ser descrita nos termos de Berta Ribeiro (1982, p.33), ainda que atualmente o período de abstenção para o trabalho artesanal seja menor e os alimentos permitidos durante o resguardo incluam alguns novos, como o macarrão e o arroz. Estes, assim como os caldos de jabuti branco e mutum mencionados pela autora, são descritos como alimentos especialmente "leves", ao contrário da maior parte das carnes vermelhas e de peixe, em especial os "de couro" (sem escamas), descritos como reimosos 6 . A abstenção destes alimentos visa garantir a cicatrização total e a eliminação do cheiro de sangue do parto, associado ao perigo de ataques do karovara. Mães e pais saem de casa o mínimo possível e evitam rigorosamente o rio e adjacências durante o resguardo. Müller (1990, p.169) menciona o karovara ${ }^{7}$ entre as causas das doenças, mas também entre os xamãs primordiais (MÜLLER, 1990, p.139). Nos maraka, quando os pajés trazem o karovara, o moynga (remédio) é transmitido para os humanos em cuias por meio da água (MÜLLER, 1990, p.159). Por outro lado, o cheiro de sangue nas cercanias do rio e a pronúncia do seu nome próximo à água provoca o espírito, que entra no corpo e o corta por dentro, fazendo as pessoas desaguarem em sangue até a morte.

No momento do parto Asurini a rede (tupava) opera como um filtro, coando o corpo sólido do bebê dos líquidos uterinos, assim como é ela quem acolhe o corpo e filtra o sangue, o suor, a urina e outros líquidos que escapam ao corpo doente. $\mathrm{Na}$

\footnotetext{
${ }^{6}$ Alimentos "reimosos" podem causar feridas na pele e dificultar a cicatrização, de forma bastante semelhante, os Karitiana definem a carne pesada como reimosa, em referência ao excesso de gordura (VAN VELDEN, 2010, p.267).

7 Karovara, não é um termo isolado, Fausto (2002, p.339) aponta diversos correlatos entre os tupi, embora possuam relevância e significados diversos conforme o grupo.
}

MARQUI, Amanda Rodrigues; MIRANDA, Xanda de Biase. Perspectivas etnográficas e infâncias indígenas: modos de ser das crianças Asuriní e Baniwa. Revista da FUNDARTE. Montenegro, p.0128, ano 20, no 42, julho/setembro de 2020.

Disponível em: http://.seer.fundarte.rs.gov.br/index.php/RevistadaFundarte/index> 30 de setembro de 2020 


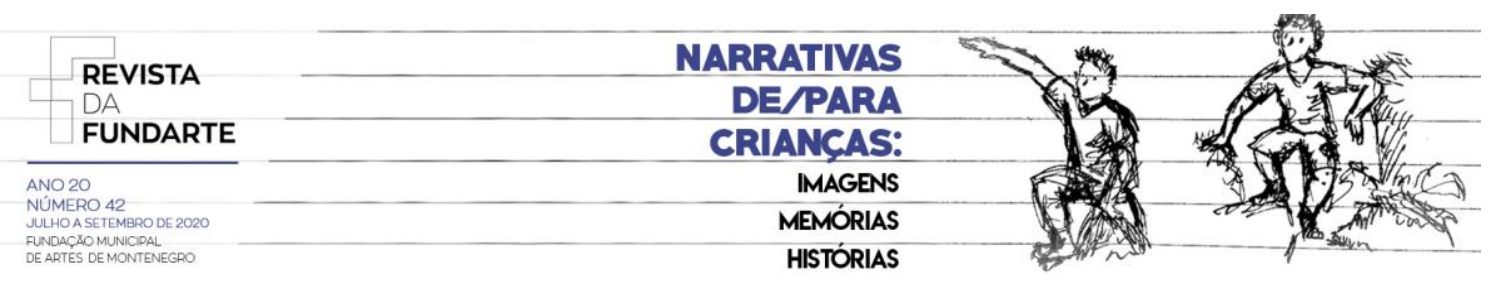

rede a mãe se banha no pós-parto. Via de regra, nos meses seguintes ao nascimento, a criança é estimulada a dormir o maior tempo possível, ficando a maior parte do tempo na rede. Depois da queda do cordão umbilical é recomendável que a criança tome muitos banhos para dar sono, pelo menos três ao dia, pois dormir engorda e fortalece o corpo. Daí em diante, o rio será parte dos dias e a rede a acolhida sempre desejável, palco de inúmeras atividades e brincadeiras. Müller registra a frequência dos banhos de rio, no mínimo três vezes por dia (MÜLLER, 2002. p.2000) e a destinação das maiores e melhores redes nos anos 80 para as poucas crianças existentes e seus pais. Além da dedicação do grupo doméstico com a decoração de seus corpos, sempre ricamente enfeitados com colares, pulseiras, enfeites de algodão nos tornozelos e cintura, pintura de jenipapo e óleo com yhyca (resina perfumada) nos cabelos (MÜLLER, 2002, p.188-207).

Ainda que o aumento das proles possa ter acarretado alterações foi possível observar a centralidade das crianças nos grupos domésticos. Encontram-se um ou outro bebê engatinhando pelo chão, mas mais comum é vê-los nas redes, tipóias ou no colo. Os parentes se desdobram em cuidados e atenções nos primeiros anos. Durante expedições breves, aquelas em que não se pernoita, por exemplo, foram observadas apenas as mães que amamentavam levando redes, exclusivamente destinadas ao seu uso e do bebê. Dentro ou fora da aldeia, nos primeiros meses a experiência da criança ocorre entre a rede, a água e os corpos dos parentes, espaços apropriados ao pequeno corpo, onde este deve permanecer até endurecer o suficiente para erguer-se e andar. Nos anos 70 a criança sequer engatinhava estava sempre no colo de adultos e ganhava o chão somente quando dominava os primeiros passos (MÜLLER, 2002, p.191).

Os Asuriní não nomeiam nem aplicam o jenipapo no corpo do recémnascido. O jenipapo devido ao risco de absorção definitiva pela pele mole, deixandoa manchada para sempre. Neste período os pais também guardam um rígido resguardo. A queda do "umbigo" marca um momento de mudança para genitores e recém-nascidos, com o abrandamento das restrições alimentares e relacionadas ao rio para os primeiros (desde que finalizada a cicatrização do pós-parto), e com a

MARQUI, Amanda Rodrigues; MIRANDA, Xanda de Biase. Perspectivas etnográficas e infâncias indígenas: modos de ser das crianças Asuriní e Baniwa. Revista da FUNDARTE. Montenegro, p.0128, ano 20, no 42, julho/setembro de 2020.

Disponível em: http://.seer.fundarte.rs.gov.br/index.php/RevistadaFundarte/index> 30 de setembro de 2020 


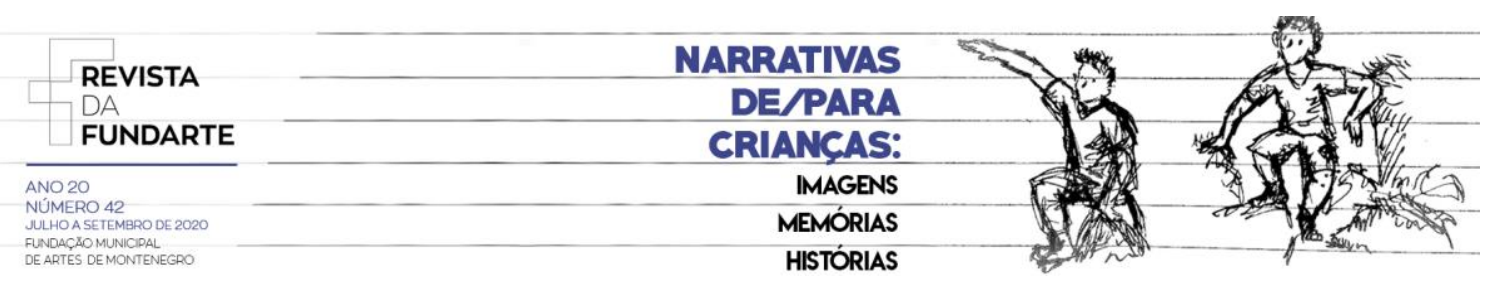

nominação e início da pintura em jenipapo para os segundos. Nossas observações sugerem, portanto, que até a cicatrização total do umbigo o recém-nascido é considerado demasiado mole para práticas de modelagem como as observadas por Viveiros de Castro (1986, p.441) entre os Araweté, Cohn (2000,p.86) entre os Xikrin ou Fausto (2001, p.396) entre os Parakanã.

As noções de ynga e anhynga, respectivamente vida e morte, são essenciais para compreensão da ontologia que orienta as práticas de fabricação do corpo infantil. Ynga pode ser definido como princípio/substância vital "que constitui o ser uno/vivente, compartilhada por espíritos e humanos" (MÜLLER, 1990, p.30), está na voz, na sombra, na pulsação do corpo e do coração (MÜLLER, 1990, p.170). A noção de doença (MÜLLER, 1990, p.168), assemelhada à imagem de um fruto podre ou semidestruído, implica na perda do ynga pela pessoa, como no suor excessivo dos estados febris. O que nos leva ao anhynga, uma "dupla noção de multiplicidade e ausência, divisão e presença” (MÜLLER, 1990, p. 31-32). Um anhynga colado ao corpo do vivente pode levá-lo a definhar até a morte (MÜLLER, 1990, p. 169). Os anhynga podem estar em qualquer lugar, a qualquer momento, podem assustar, sequestrar e causar doenças (MÜLLER, 1984/85, p.108). Mas um anhynga não é, por definição, um vivente. Viventes possuem ynga são seres unos em oposição à noção de dividido, ausente, cujo designativo é anhynga" (MÜLLER, 1990, p.245).

Desta forma, quanto menor a criança, mais moles os ossos, mais permeável a pele, mais solúvel e menos íntegra a forma do corpo. Consequentemente, menor a capacidade de manter o ynga, o que contribui para que as crianças sejam presas fáceis para os anhynga. Portanto, o grupo doméstico se ocupa em garanti-lo abundantemente através da pintura com jenipapo e com a ajuda dos pajés ${ }^{8}$. O alimento primorosamente preparado e as minuciosas habilidades desenvolvidas, especialmente no exercício da culinária e da olaria se entrelaçam, formando uma rede de substâncias duras e moles, secas e molhadas, naturais e

\footnotetext{
8 Müller (1990, p. 112-113, 147) registra a notável presença dos pequenos em todos nos ritos terapêuticos.
}

MARQUI, Amanda Rodrigues; MIRANDA, Xanda de Biase. Perspectivas etnográficas e infâncias indígenas: modos de ser das crianças Asuriní e Baniwa. Revista da FUNDARTE. Montenegro, p.0128, ano 20, no 42, julho/setembro de 2020.

Disponível em: http://.seer.fundarte.rs.gov.br/index.php/RevistadaFundarte/index> 30 de setembro de 2020 


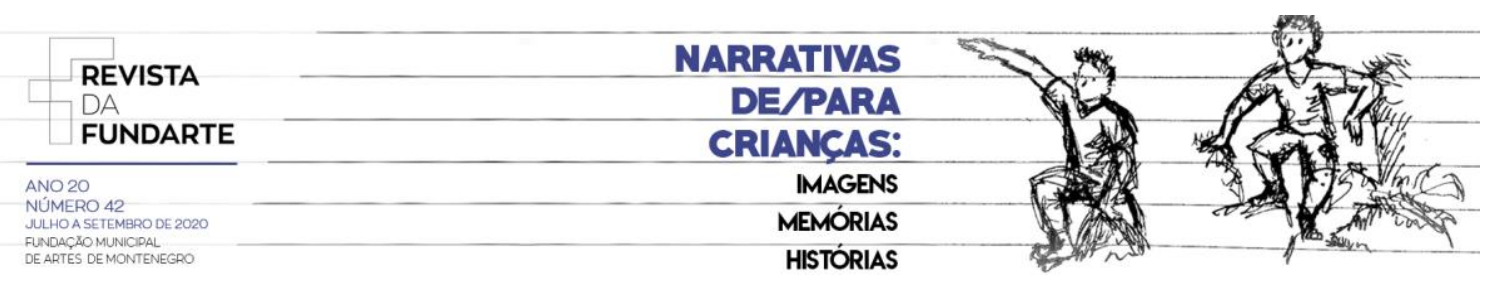

sobrenaturais na qual as mulheres filtram e forjam o corpo da criança. Inicialmente, trata-se de separar o que é vivo (dentro) do que não é (fora). Durante todo o período de crescimento do corpo os pais incentivam os banhos para manter a pele lisa e úmida, pois a água potencializa e reanima os efeitos do jenipapo. O jenipapo está sempre presente no cotidiano e as mães costumam aplicá-lo pequenas doses nos pés ou mãos dos bebês para que se acostumem "pukuap" com suas propriedades. $O$ uso das resinas perfumadas e do urucum foi abandonado por conta de sua ausência na região, mas era aplicado na cabeça dos bebês para afastar os anhynga, que detestam tanto cheiro quanto gosto. $O$ jovem xamã comparou o urucum a "uma vacina, que protege o corpo" e o jenipapo, igualmente repulsivo aos anhynga, a "uma vitamina, que alimenta a criança e a faz crescer". Por isso o jenipapo é generosamente aplicado pelas mães durante todo o período de crescimento corporal.

Assim, inicialmente a criança transita em terra molhada, no universo de Tauva, cuja imagem no mundo atual é a do peixe pacu (MÜLLER, 1990, p.192). Na narrativa mítica, Tauvyma ${ }^{9}$ é a mulher que teve seu marido, a anta, morto pelo próprio irmão boakara, guerreiro e caçador, e por isso foi embora do mundo humano, se jogando no rio e se transformando no sobrenatural Tauva. Antes, Tauvyma acompanha as abelhas ao poço de coleta de barro e faz muitos tipos de panelas, pois elas se quebram nos seus encontros com a anta. Ela se entristece ao ver os vestígios do marido morto, se recusa a comer sua carne e inaugura o uso da tatuagem ao aplicá-la para garantir a sobrevivência do irmão (MÜLLER, 1990, p.336337). Na performance ritual, a mulher madura na qualidade de Tauvyma invoca a Cobra e outros sobrenaturais, tal como nos rituais xamanísticos em geral, para proteger a vida do boakara com o ynga transmitido através do suco do jenipapo sobre as incisões da tatuagem (MÜLLER, 1990, p.109-110).

Analisando a produção da cerâmica, Silva (2000, p.63) registra que a operação de alisar a vasilha é demorada e realizada com muito esmero, pois,

9 Tauvyma, tauva + yma sufixo indicador de futuro,p. aquela que será Tauva (MÜLLER, 1990, p.200).

MARQUI, Amanda Rodrigues; MIRANDA, Xanda de Biase. Perspectivas etnográficas e infâncias indígenas: modos de ser das crianças Asuriní e Baniwa. Revista da FUNDARTE. Montenegro, p.0128, ano 20, no 42, julho/setembro de 2020.

Disponível em: http://.seer.fundarte.rs.gov.br/index.php/RevistadaFundarte/index> 30 de setembro de 2020 


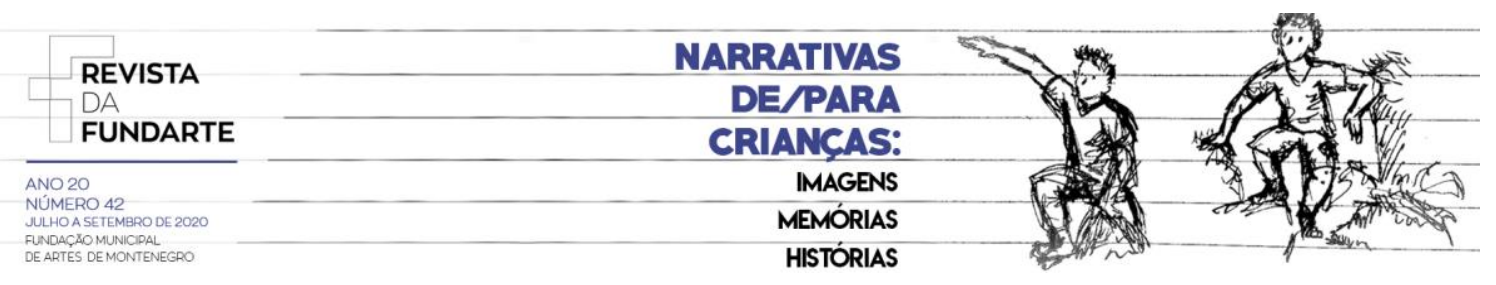

segundo as oleiras, deve ficar "lisa como pele de gente". Dado que a autora compreende ao ouvir o mito em que Maíra "molda o corpo do seu filho Kyty, alisa sua pele (iapire) para ele ficar bonito e, enquanto faz isso, 'Kyty não pode se mexer, até ficar duro"' (SILVA, 2000, p.64). Na história Kyty 10 tinha a pele feia, cheia de feridas, era kurubento (perebento, como dizem hoje em dia), por isso foi preterido pela mulher amada. Resolveu procurar Maíra e com incrível esforço o alcançou. Maíra acolheu seus lamentos, arrancou a pele feia do seu corpo e jogou-a no rio, onde ela se transformou no primeiro jacaré. Moldou então uma nova pele, alisando-a com muito capricho para que ficasse lisa e bonita. Enquanto fazia isso, Kyty não podia se mexer, até a pele ficar dura, pois estava mole como o barro.

Da mesma forma não se mexem os pequenos enquanto são pintados, senão o jenipapo molhado borra, desfazendo os delicados desenhos. Ter o corpo pintado destaque-se, é um exercício de imobilidade e paciência ao qual toda criança é acostumada. Importa que entre os Asuriní a analogia entre corpos e vasilhames cerâmicos é particularmente literal e inevitável. O corpo recém-nascido identificado com a peça no início do processo de moldagem, quando a forma imposta ao barro molhado ainda não desenvolveu a propriedade de comportar os conteúdos que lhe caberão (o barro absorve a água, tal qual a pele mole absorve o jenipapo). E os cuidados com a aplicação de jenipapo, incluindo os banhos, sobre o corpo em endurecimento/crescimento com o vasilhame durante os processos de alisamento, pintura e colocação de resina. A capacidade dos corpos comportarem adequadamente o ynga se dará gradualmente, conforme ossos e pele aumentam e endurecem.

Os interditos relacionados ao sobrenatural Tauva vinculam o barro, a panela, o corpo da mulher e a capacidade de gestação. Como registrado por Silva (2000, p.73), durante a manufatura "a panela não seca direito" se as mulheres beberem, comerem, urinarem ou defecarem. Quando uma ceramista morre, suas panelas são quebradas para evitar o anhynga. O barro não pode ser coletado, ou

\footnotetext{
${ }^{10}$ A história de Kyty foi registrada por Müller (1990, p. 323-327), ouvi de Takamui, Kwatireí e outras versões semelhantes.
}

MARQUI, Amanda Rodrigues; MIRANDA, Xanda de Biase. Perspectivas etnográficas e infâncias indígenas: modos de ser das crianças Asuriní e Baniwa. Revista da FUNDARTE. Montenegro, p.0128, ano 20, no 42, julho/setembro de 2020.

Disponível em: http://.seer.fundarte.rs.gov.br/index.php/RevistadaFundarte/index> 30 de setembro de 2020 


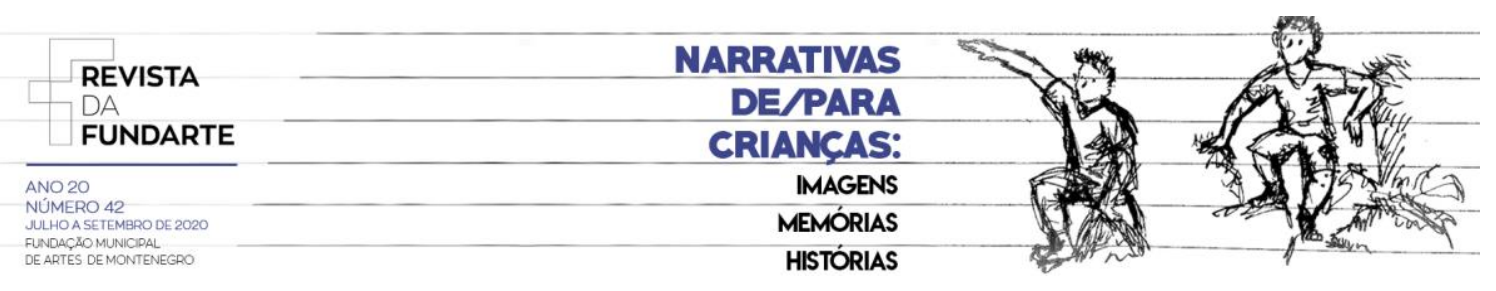

mesmo tocado por homens, nem por mulheres grávidas e menstruadas, pois isso acarreta a quebra dos vasilhames na hora da queima. Quando uma mulher gesta ou menstrua, não pode exercer o papel de Tauvyva ${ }^{11}$ no ritual de Tauva. Não uma metáfora, temos uma metonímia que nos permite tomar o vasilhame cerâmico como um pequeno corpo, vinculado ao corpo da oleira. E nos sugere que cabe à oleira pintora a arte de fazer corpos, de moldar formas apropriadas ao ynga.

Olaria e pintura são domínios consubstanciais quando consideramos a Tauva, pois, na performance ritual é a oleira quem maneja o jenipapo da tatuagem e da pintura corporal. Se a cerâmica é uma arte delicada sobre o barro mole, sujeita a perder a forma durante o endurecimento, a pintura aplicada posteriormente deforma, ou dá forma. Uma panela bem acabada pode parecer disforme por conta de uma pintura mal aplicada e um vasilhame irregular pode ganhar simetria com um grafismo bem proporcionado. As mulheres exercitam longamente essas habilidades de modelagem e projeção em diversos suportes tridimensionais, como cuias e bancos de madeira. Mas a panela, segundo Müller (1990, p.220), "constitui o suporte em que maior variedade de padrões de desenho e combinações podem ser realizadas e onde a criatividade individual se exerce mais plenamente". A pintura com padrões geométricos confere ao corpo um caráter propriamente humano e diferencia gêneros (MÜLLER, 1990, p.227). Nos corpos masculinos, a pirinyna marca a divisão horizontal de ombro a ombro e delimita um desenho em forma ovalada em cada ombro, preenchido com estampas geométricas. Nos corpos femininos, obedecerá a uma divisão vertical, que marca o ventre. Estas divisões horizontais ou verticais determinam a distribuição dos desenhos no corpo. Outras partes do corpo são divididas da mesma forma para ambos os sexos.

Já a pintura inteiramente em preto ajemo'ona, não respeita os limites formais que distinguem os gêneros e a anatomia, sendo definida por Müller (2009, p.165) como uma "roupagem liminar" do estado de incorporação do personagem Kavara, cuja mítica introduz a noção da divisão do eu, causada pela morte. Kavara e seu

${ }^{11}$ A tauvyva normalmente é chamada de "dona da festa" em português, mas chamá-la de "a que frutifica o espírito da Tauva" parece-me mais exato. Yva: é um sufixo que, junto com um nome de fruta, significa a árvore daquela fruta (MONSERRAT, 1998, p.41);

MARQUI, Amanda Rodrigues; MIRANDA, Xanda de Biase. Perspectivas etnográficas e infâncias indígenas: modos de ser das crianças Asuriní e Baniwa. Revista da FUNDARTE. Montenegro, p.0128, ano 20, no 42, julho/setembro de 2020.

Disponível em: http://.seer.fundarte.rs.gov.br/index.php/RevistadaFundarte/index> 30 de setembro de 2020 


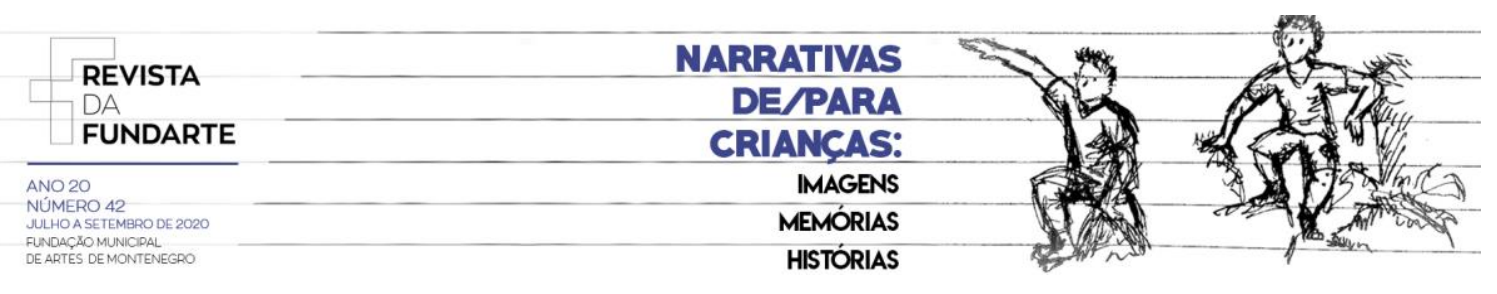

companheiro vão caçar e são atacados por um inimigo. O companheiro morre e ele volta para a aldeia, mas é perseguido pelos pedaços do corpo do amigo morto (fígado, coração, braço, perna e sangue). Na aldeia, fazem uma festa e cantam sobre o braço do morto a noite toda, de manhã os anhynga vão embora. Mas a esposa do morto fala o seu nome, então ele volta e a leva com ele. Kavara é uma das facetas de anhynga, materializada no interdito ao nome dos mortos. No cotidiano as mulheres não cobrem corpos inteiramente de jenipapo, manejam esta substância de forma articulada aos saberes kwasiat ${ }^{12}$.

Nossas observações em campo nos permitem afirmar os efeitos profiláticos (vitamínicos, nutritivos) do jenipapo (também registrados por outros autores, como Gallois (1992) e Demarchi (2010), associadas à agência diferenciada dos padrões na fabricação da forma corporal. A pirinyna (a linha ou linhas paralelas), alonga o corpo e acelera o crescimento. Determinados grafismos são considerados menos adequados para a criança, como mytupepa (asa de mutum), que pode confundir o crescimento, atrapalhando seu sentido. Tamakyjuak (tamaky = perna, canela; juak = pintura), imprime velocidade e destreza. Juakete, a pintura verdadeira está entre as mais utilizadas, sendo particularmente recomendável para acelerar a recuperação do corpo doente. Complementam a modelagem os cordões de algodão - tapukura nas pernas e kaapuawa nos braços dos meninos e pinimaia na cintura das meninas, que servem para engrossar estes membros, reforçando características de gênero desejáveis ao corpo.

Se por um lado o jenipapo separa substancialmente corpos vivos de partes mortas, por outro, o desenho gera unidade, coesão entre membros, seu efeito poderia seria ser descrito como de "membramento", em oposição ao desmembramento do corpo representado pela morte. O sufixo -er/-per/-wer indica passado nominal e quando aplicado ao léxico dos corpos marca esta diferença entre o corpo íntegro, que contém ynga e o corpo desmembrado, o ex-corpo. Neste

12 Termo traduzido comumente na literatura como desenho. Em um artigo sobre os "desenhos semânticos" Kayabi, Ribeiro compara os termos kwatsiapat ou kwatsiat Kayabi que significam "desenho" ao kwasiat dos Asuriní. E aponta serem comuns os cognatos do termo nas línguas tupi, assim como seu uso para a tradução de desenho e escrita (1987, p.270).

MARQUI, Amanda Rodrigues; MIRANDA, Xanda de Biase. Perspectivas etnográficas e infâncias indígenas: modos de ser das crianças Asuriní e Baniwa. Revista da FUNDARTE. Montenegro, p.0128, ano 20, no 42, julho/setembro de 2020.

Disponível em: http://.seer.fundarte.rs.gov.br/index.php/RevistadaFundarte/index> 30 de setembro de 2020 


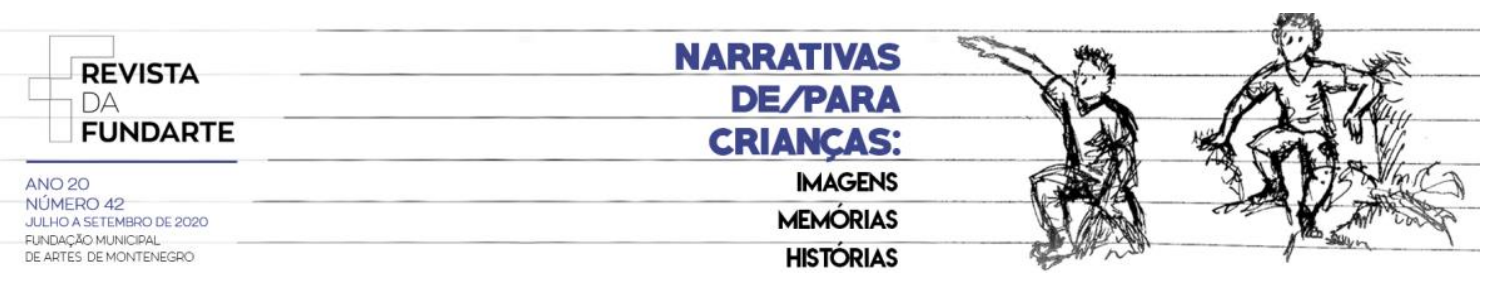

caso, os Asuriní se referem, precisamente, a ex-partes de $\operatorname{corpos}^{13}$. Os esforços de homens e mulheres se dão no sentido de estimular o crescimento para cima, alongando, e para os lados, engordando, para que o pequeno corpo se mantenha inteiro (u'awe), não se parta, não seja apenas parte de outro algo, um pedaço (myryny). Como na imagem sugerida pelo termo amu'i que combina a $1^{\text {a }}$ OS com os causativos -mu e $-i$ = pequeno; "tornei pequeno", "esfarelei" (MONSERRAT, 1988, p.13), o demasiado pequeno é sinônimo de partido, de quebrado, o antônimo de um inteiro e, portanto, o oposto de um corpo capaz de possuir ynga.

$\mathrm{Na}$ narrativa mítica, o desenho provém de Anhyngakwasiat ${ }^{14}$, anhynga primordial que fez para si um corpo com a pintura, de onde se originam a habilidade de pintar juak e o conhecimento sobre os padrões geométricos kwasiat. Anhyngavuí ouviu o barulhento e agressivo Anhyngakwasiat, viu seu corpo decorado e se perguntou "o que eu vi? É bonito", o corpo era uma junção de partes, cada qual com um padrão diferente. Observando de longe Anhyngavuí aprendeu os padrões, que reproduziu no trançado de flechas, esteiras e peneiras. É justamente um anhynga, por definição um não inteiro, um dividido, quem demonstra aos Asuriní que de pequenas partes se podem fazer inteiros. Como nos esclarece Müller, a tensão entre unidade e dispersão se desdobra em um terceiro termo, a representação, com os desenhos "o anhynga existe, como unidade" (MÜlLER, 1990, p.32, 272), ou seja, há um corpo. Assim, o suporte "por excelência" para a aplicação do grafismo é o corpo humano, "forma concebida como tal na mitologia e reafirmada na transposição da nomenclatura da anatomia humana à das panelas de cerâmica" (MÜLLER, 1990, p.220)15.

\footnotetext{
${ }^{13}$ Se relacionados ao corpo são sufixos que indicam a morte, Monserrat (1988, p. 33) cita alguns exemplos,p. jauti papera "ex-pata do jabuti", jauti apepera, "ex-casco de jabuti". O sufixo também é aplicado para enfatizar que algo já não é como em tava "aldeia" e tavera, "ex-aldeia", aldeia que já não é habitada.

${ }^{14}$ Müller (1990, p.250-272) desenvolve uma detalhada análise sobre este mito, relacionando à noção de representação como constitutiva da pessoa, conferindo ao ser o estatuto de uno, vivente.

15 A divisão das partes da panela para a pintura representa o corpo humano, em uma versão, digamos, básica; bunda (rekará), corpo (sem denominação específica), cabeça (akynga) e pescoço (ajora) que aparece apenas em alguns modelos de panela (MÜLLER,1990, p.218).
}

MARQUI, Amanda Rodrigues; MIRANDA, Xanda de Biase. Perspectivas etnográficas e infâncias indígenas: modos de ser das crianças Asuriní e Baniwa. Revista da FUNDARTE. Montenegro, p.0128, ano 20, no 42, julho/setembro de 2020.

Disponível em: http://.seer.fundarte.rs.gov.br/index.php/RevistadaFundarte/index> 30 de setembro de 2020 


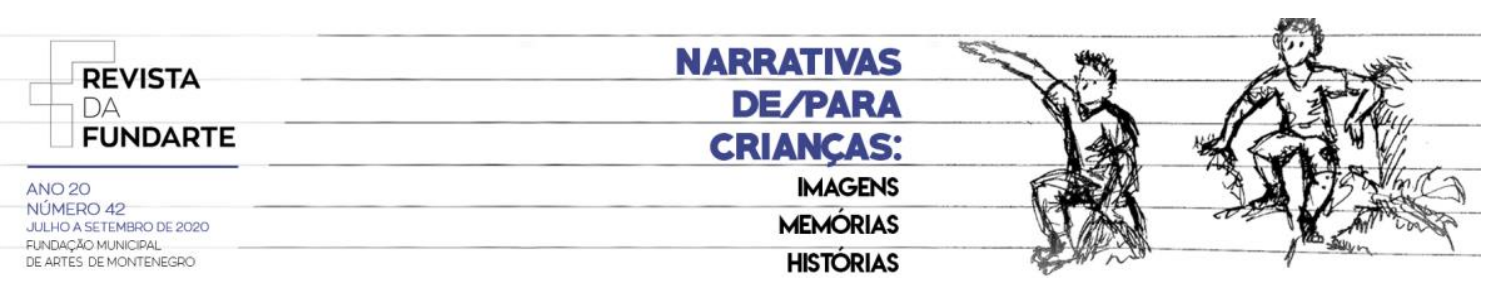

Diversas habilidades são recrutadas para que o pequeno corpo seja forte, resista ao nascimento e endurecimento, tal qual o vasilhame cerâmico há de ser. Mas não somente, o corpo deve ser belo, de uma beleza ontológica, a forma perfeita de kyty moldada por Maíra (MÜLLER, 1990, p.194), o que implica nas ideias de proporcionalidade da forma e de uma pele perfeitamente lisa, alisada com água e jenipapo pelas mulheres. Em juakete a forma se identifica ao suporte, que domina o conteúdo, assim, para Müller (1990, p.229), o desenho subordina-se à forma do corpo. Com base nas observações deste campo podemos considerar o contrário igualmente verdadeiro - o corpo subordina-se ao desenho, que pressupõe um corpo. Não qualquer corpo, o corpo belo moldado por Maíra. Neste sentido, quando a prática leva à perfeição, quando a habilidade xamânica alcança a maturidade, temos a tayngava ${ }^{16}$, padrão preponderante nos desenhos e boneco antropomórfico usado nos maraká. O "ser humano/vivente/uno" representado na tayngava se diferencia da ideia de kwasiat (o repertório) e da figuração ou desenho do corpo (avaraingava) pelo princípio que "define humanos e outros viventes, isto é, que possuem a substância ynga”. Assim, temos na tayngava, um vivente que prescinde de corpo, pura projeção da imagem, incorpóreo, mas íntegro e continente exato para o ynga.

A fabricação dos corpos combina diversas técnicas, cordões nos membros, imobilidade temporária durante a aplicação, a agência do jenipapo, banhos que reativam e potencializam estes efeitos e, por fim, a visibilidade e o caráter propriamente humano da forma dados pela pintura. A beleza captura o olhar como uma "tukaia", uma tocaia, armadilha. E o corpo belamente pintado se diferencia do fundo quando é olhado. Diante do olhar sua forma una é ressaltada, o que lhe reitera a integridade. Assim, no cotidiano o grupo doméstico se dedica a acostumar o kunumi a ficar bonito, recrutando o caráter "visualmente compulsivo" dos desenhos

\footnotetext{
${ }^{16}$ Müller (1990, p.245) sinaliza a associação entre as noções de ynga (raiz yng) e ayangava (raiz ayng), traduzida por imagem, representação. Com o sufixo " $t$ " que indica possuidor humano, tayngava significa imagem do ser humano. Müller (1990, p.247-248) aponta paralelismos e diferenças com os cognatos taangap kayabi, ta'angap kamayurá e ta'anga waiãpi.
}

MARQUI, Amanda Rodrigues; MIRANDA, Xanda de Biase. Perspectivas etnográficas e infâncias indígenas: modos de ser das crianças Asuriní e Baniwa. Revista da FUNDARTE. Montenegro, p.0128, ano 20, no 42, julho/setembro de 2020.

Disponível em: http://.seer.fundarte.rs.gov.br/index.php/RevistadaFundarte/index> 30 de setembro de 2020 


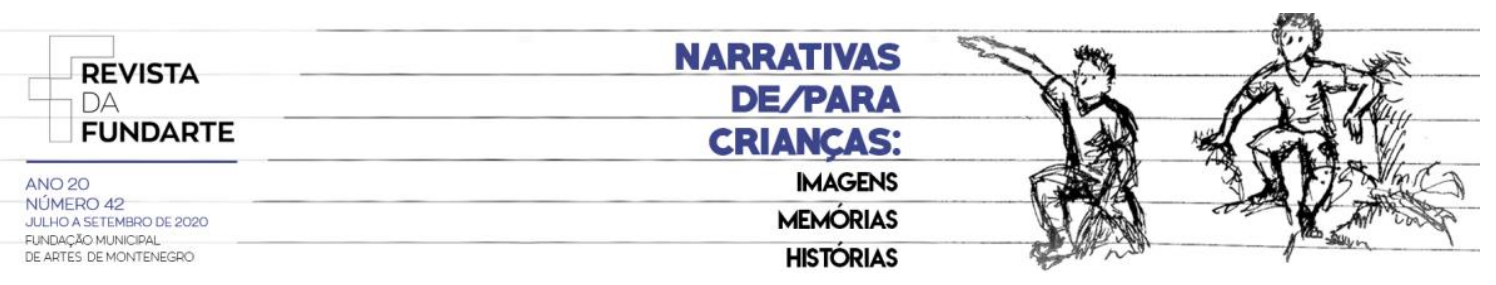

"no sentido de focalizar a atenção sobre a superfície contínua da forma corporal", como descreveria Gow (1988, p.19).

\section{As crianças baniwa}

$\mathrm{Na}$ primeira fase da vida, a responsabilidade pela criança é quase exclusivamente da mãe, que a leva para banhar logo cedo, a alimenta e permanece o tempo todo com ela. Os cuidados com os banhos e alimentação são uma das ações mais valorizados no ponto de vista dos Baniwa para a fabricação de pessoas belas/bonitas e disciplinadas. As crianças de colo são kodapeta até o momento em que começam a engatinhar. Esse período é subdividido em três fases: Keramo, Tarawadali e Hitsiakada. Keramo são as crianças recém-nascidas que recebem uma série de cuidados especiais em relação ao primeiro banho (benzimento da água) e cuidados dos pais, como a couvade e a restrição alimentar, consumindo preferencialmente apenas caribé e chibé, bebidas produzidas a partir da mistura de água com beiju e farinha, respectivamente. Quando o bebê passa a ter um pouco de firmeza no corpo são designadas tarawadali e quando começa a engatinhar são hitsiakada. No momento em que os bebês ficam com o corpo mais firme, o cuidado começa a ser dividido com seus irmãos mais velhos, se os houver, e quando eles começam a engatinhar passam a ter maior interação com os demais membros da família e a presença do pai se torna mais efetiva nos cuidados com o bebê. Nesta fase as relações da criança se ampliam, passando da mãe para outras pessoas da casa e estendendo-se aos demais membros da comunidade.

Depois que a criança começa a andar ela é denominada patapatadali, menino, e patapatadaro, menina. Enquanto a criança já anda embora sempre caia e por isso é comum ter sempre alguém por perto a observando -, os meninos são makodalittoa e as meninas makadarottoa. Nesta fase, a criança ainda não fala, apenas formula sons. Quando as crianças começam a falar e interagir com seus pais é um período fundamental de aprendizagem, as meninas são kakodaroina padapena e kakodali padapena, menino. A partir desse momento as crianças devem 


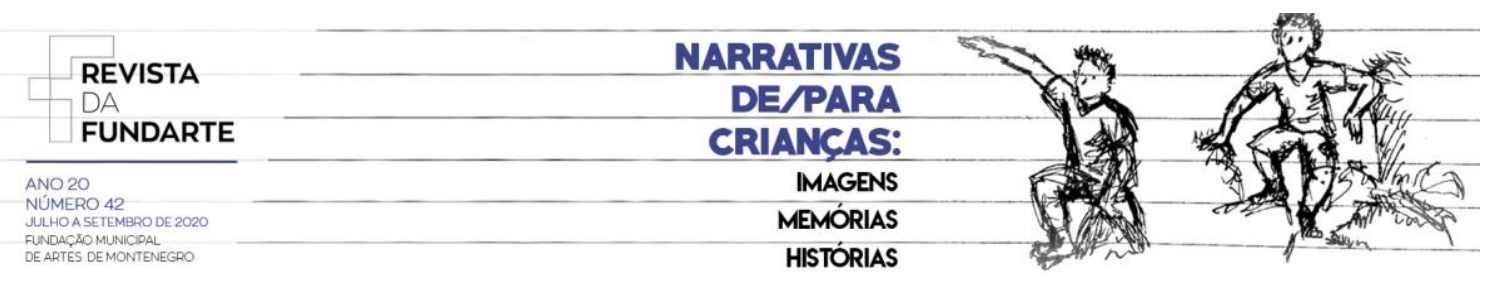

acompanhar seus familiares, pai e mãe, e receber conselhos ${ }^{17}$. Quando alcançam a fase tsiandalina, menino e inaro hadalina, meninas, as crianças começam a ajudar nas tarefas cotidianas como a pesca e a roça. Neste momento é indicado aos pais transmitir os ensinamentos importantes relacionados ao gênero para a formação de meninas e meninos. Neste sentido, os meninos permanecem mais tempo com seus pais e irmãos mais velhos e as meninas ficam mais com suas mães. A fase seguinte é denominada keñoa walhipalikani, cujo significado é começar a ser jovem, que, em outras palavras, contempla o período de transição da infância para a fase que antecede o ritual de passagem, o kalidzamai (WRIGHT, 1993). Nesta etapa são aprofundados os conhecimentos imprescindíveis à vida Baniwa, como as técnicas de pesca e caça, o plantio nas roças e a produção de derivados da mandioca, o reconhecimento das plantas alimentares, venenosas e medicinais.

De acordo com Diniz (2011, p.100) não é simples identificar os critérios que definem as mudanças de uma fase de vida para outra; o que se pode assegurar é que este processo tem longa continuidade na formação da pessoa baniwa, mesmo que seja marcado por contradições e especificidades, pois levam em conta a demonstração de maior ou menor dependência das crianças e jovens de seus familiares. Neste sentido, também são considerados alguns aspectos como autocontrole para a disciplina, os impulsos e a capacidade de realizar atividades de subsistência que remetem a noção de saber-fazer. Além disso, é importante considerar que por meio da realização de atividades do cotidiano vão se estabelecendo as distinções de gênero.

São nas águas que as crianças descobrem e aprendem várias habilidades importantes em seu cotidiano ${ }^{18}$. O porto principal da comunidade de Vista Alegre

\footnotetext{
17 Para maiores informações sobre os conselhos e aconselhamentos baniwa cf. Marqui (2017, p. 9295)

${ }^{18} \mathrm{O}$ trabalho de Mead (1930) sobre a infância manus em Samoa foi pioneiro na observação e análise dos processos educativos das crianças durante os momentos em que estavam nas águas. Seu objetivo era compreender como as crianças aprendem as habilidades físicas para sobrevivência em um vilarejo cercado pelo mar. Há etnografias sobre infâncias indígenas que descrevem as brincadeiras e atividades das crianças nas águas (cf. COHN, 2000; PEREIRA, 2013; MIRANDA 2014).
}

MARQUI, Amanda Rodrigues; MIRANDA, Xanda de Biase. Perspectivas etnográficas e infâncias indígenas: modos de ser das crianças Asuriní e Baniwa. Revista da FUNDARTE. Montenegro, p.0128, ano 20, no 42, julho/setembro de 2020.

Disponível em: http://.seer.fundarte.rs.gov.br/index.php/RevistadaFundarte/index> 30 de setembro de 2020 


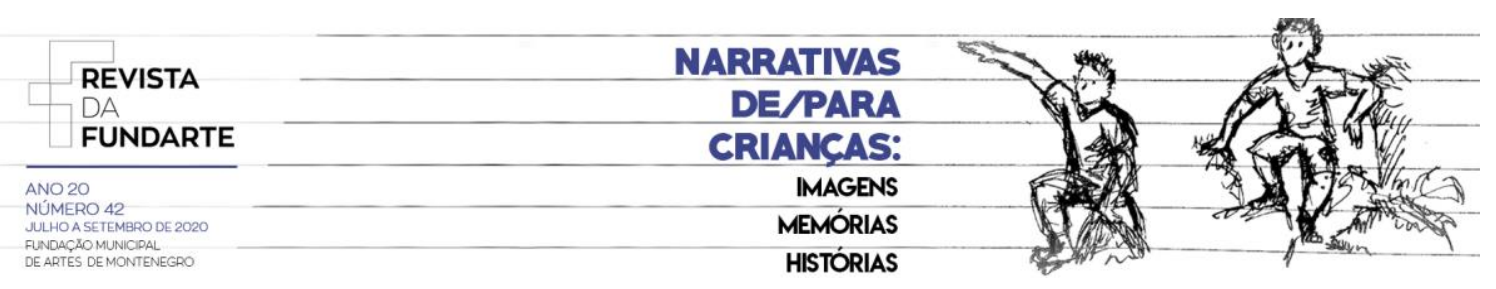

ficava próximo ao local onde a pesquisadora ficou, deste modo foi possível observar e acompanhar as crianças que desciam até o rio ao longo do dia. Os banhos nos rios são frequentes e motivo de alegria e diversão entre as crianças. Elas banham em grupos de primos ou irmãos ao longo do dia em certos lugares na comunidade e também próximo ao porto familiar. O primeiro banho do dia é realizado com o pai, antes do amanhecer, porque a mãe já está preparando o mingau. No final da tarde as mães acompanham seus filhos à beira do rio para o último banho do dia. Para as crianças os banhos são momentos oportunos para as brincadeiras e também uma forma de aprendizado da disciplina de cuidado e limpeza do corpo baniwa. De acordo com Garnelo (2003, p.78), as principais regras de higiene entre os Baniwa são os banhos, "que devem ser tomados ao acordar, antes do preparo das refeições (mulheres), quando a pessoa estiver suada e fundamentalmente antes se alimentar". As regras de higiene corporal explicitam as tensões entre humanos e animaisespíritos como os yoopinai ${ }^{19}$ (idem).

Quando havia merenda ${ }^{20}$ no centro comunitário, as crianças mal terminavam de serem servidas e já saiam rapidamente carregando seus pratos e comendo durante o caminho para o porto principal. Neste banho após a escola era comum que houvesse crianças de toda a comunidade. Este era um momento de diversão e brincadeira, as crianças ficavam em pé e seguravam os pratos com as mãos ${ }^{21}$, quando terminavam de se alimentar lavavam os pratos que levariam depois para suas casas. As crianças permaneciam por muito tempo nadando e brincando, poderiam também brincar com as canoas próximas do porto. As principais brincadeiras eram disputas a nado e com canoa, pega-pega, pulos acrobáticos e

\footnotetext{
19 "Os yoopinai são espíritos da mata, da água e do ar; são considerados 'donos' dos rios, dos animais e das florestas, sendo, por isso, agressores potenciais dos humanos que, para sobreviver, precisam predar esses recursos. Seus ataques podem causar várias doenças" (GARNELO: 2003, p.67).

20 Denominação regional para a alimentação realizada no contexto escolar. Para maiores informações sobre a merenda no centro comunitário, cf. Marqui (2017, p. cap. 4).

${ }^{21}$ As crianças apenas se alimentavam no rio nesta ocasião da merenda ser compartilhada no centro comunitário.
}

MARQUI, Amanda Rodrigues; MIRANDA, Xanda de Biase. Perspectivas etnográficas e infâncias indígenas: modos de ser das crianças Asuriní e Baniwa. Revista da FUNDARTE. Montenegro, p.0128, ano 20, no 42, julho/setembro de 2020.

Disponível em: http://.seer.fundarte.rs.gov.br/index.php/RevistadaFundarte/index> 30 de setembro de 2020 


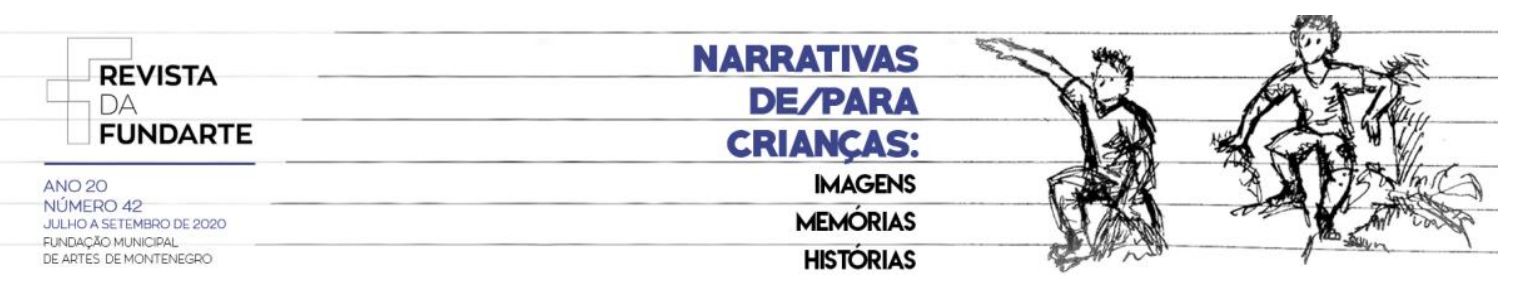

músculo ${ }^{22}$. As crianças demonstravam grande habilidade em nadar e remar contra a correnteza e permanecer por muito tempo debaixo d'água sem respirar.

Há dois aspectos pertinentes aos banhos das crianças que podem ser comparados com os jovens e adultos: elas não seguem as delimitações de gênero ${ }^{23}$ e as crianças pequenas tomam banho sem roupas, o que ocorre somente com os mais velhos, que fazem isto em locais reservados ou quando estão sozinhos. As mulheres mais velhas podem banhar-se sem blusa. $O$ banho matutino feminino acontece antes do alvorecer e no retorno elas trazem consigo a água para o preparo do mingau, depois de voltarem da roça é comum também banharem-se e, no final da tarde tomam o último banho antes da refeição coletiva ${ }^{24}$. As mulheres solteiras tomam banhos com suas mães, irmãs e primas que residem na mesma comunidade, as casadas tomam banho com seus filhos ${ }^{25}$. Os homens tomam banhos individuais no cotidiano, exceto pela manhã, quando levam as crianças para o rio e aos domingos após os jogos de futebol, quando os times descem juntos para a beira do rio.

\section{Sobre mobilidade e socialidade}

\section{As crianças Asuriní}

Como destaca Müller (2002, p.197), não há entre os Asuriní, um sistema de parentesco baseado em clãs, metades, linhagens ou qualquer outra estrutura que

\footnotetext{
22 Havia um menino sempre que quando via a pesquisadora na beira do rio, dispunha seus braços de forma a aparentar sua força e dizia: "MÚS-CU-LO", em seguida dava um pulo acrobático na água. Essa prática virou uma brincadeira entre os demais meninos da comunidade, no final do trabalho de campo era frequente os meninos ficarem em fila e repetir a palavra para pular na água.

${ }^{23}$ Muller notou a separação de gênero durante os banhos, segundo ela "Os homens e meninos se banhavam atrás das rochas, separados das mulheres - isto era algo importante em seu código de ética" (2003, p.33). Demais etnografias também apontaram as restrições entre os gêneros durante o banho (cf. GARNELO 2003; DINIZ 2011).

${ }^{24} \mathrm{~A}$ refeição coletiva vespertina é realizada no centro comunitário com a presença de adultos, velhos e crianças de colo.

${ }^{25}$ Para maiores detalhes sobre higiene e limpeza corporal feminina cf. Garnelo (2003).
}

MARQUI, Amanda Rodrigues; MIRANDA, Xanda de Biase. Perspectivas etnográficas e infâncias indígenas: modos de ser das crianças Asuriní e Baniwa. Revista da FUNDARTE. Montenegro, p.0128, ano 20, no 42, julho/setembro de 2020.

Disponível em: http://seer.fundarte.rs.gov.br/index.php/RevistadaFundarte/index> 30 de setembro de 2020 


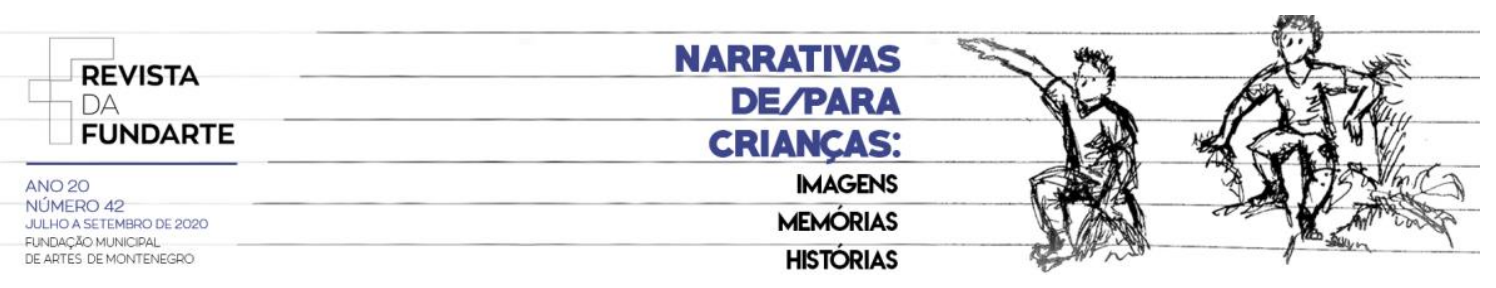

situe a pessoa como membro de um grupo, definindo relações sociais, comportamento ou identidade. O pertencimento a um grupo familiar atua como organizador das atividades e relações sociais, sendo constitutivo para a identidade Asuriní. Cada grupo doméstico ocupa um conjunto de construções que inclui, além das moradias onde se dorme, as cozinhas, as áreas de trabalho e de armazenamento. O pátio que se forma no centro destas construções, onde um grupo doméstico descansa, come e passa boa parte do dia é chamado de ukara, terreiro. O ukara e imediações são os espaços onde se pressupõe que a criança permaneça, antigamente não saiam deste perímetro sem a companhia de um adulto, de maneira que muitas nem chegavam a conviver com outras crianças (MÜLLER, 2002, p. 201, 204). Atualmente, a volumosa e agitada população infantil circula por espaços mais abrangentes, o que não significa que tenham livre circulação em todos os espaços. Em raras ocasiões, se vê um membro de um grupo doméstico dentro ou próximo do conjunto de construções de outro grupo, este trânsito não é exatamente proibido, mas certamente se dá em território alheio. Esta espacialidade delimitada pela área doméstica se desdobra nos espaços compartilhados, como os locais no rio onde se banham e atracam as canoas, os caminhos que usam para atravessar a aldeia, as picadas que levam às roças, a tavyve (casa comunal) e as casas de fabrico de farinha. As visitas a outras sessões domésticas ocorrem em diversas oportunidades, quando este encontro se dá deliberada e propositalmente, mas não no cotidiano.

O recorte de ukara nos permitiu observar que a mobilidade infantil ocorre livremente somente nos espaços dados pelo parentesco e pela comensalidade. Se olharmos o conjunto de relações dado neste espaço de mobilidade geográfica e social da criança nos deparamos com uma morfologia de grupo constituída a partir de um casal mais velho, que agrega em torno do seu terreiro dois ou três casais de filhos adultos e/ou jovens, com filhos pequenos. A forte influência exercida pelos casais mais velhos, a bilateralidade dada na nominação e a noção de pertencimento aos ukara se explicitam nos casos de adoção. As três crianças pequenas que nasceram de casamentos desfeitos ou relações fora do casamento moram com os pais dos pais. Os novos maridos normalmente não desejam criar essas crianças e indígenas: modos de ser das crianças Asuriní e Baniwa. Revista da FUNDARTE. Montenegro, p.0128, ano 20, no 42, julho/setembro de 2020.

Disponível em: http://.seer.fundarte.rs.gov.br/index.php/RevistadaFundarte/index> 30 de setembro de 2020 


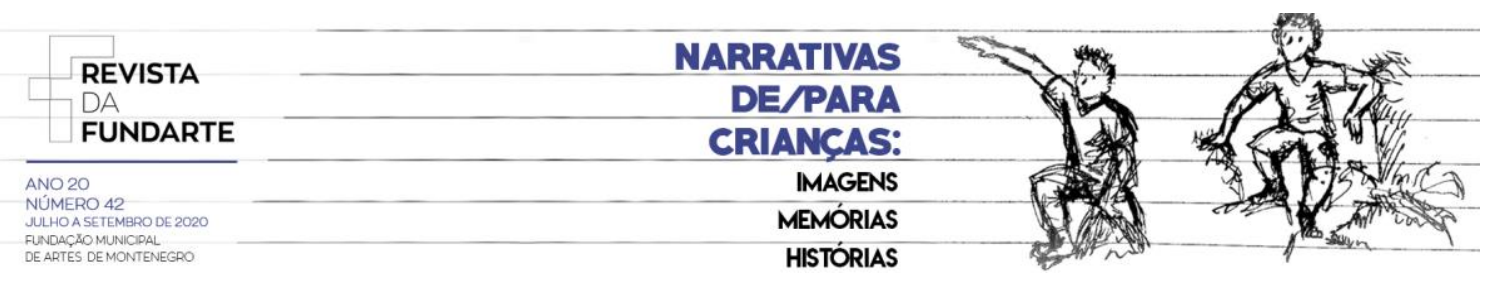

quando as mães se mudam, permanecem na casa dos avós. Duas crianças nestas condições moram com os avós maternos e uma com os paternos. Desta forma, a tendência é de que as crianças cresçam no ukara em que nasceram, seja dos pais do pai ou da mãe. Assim, apesar das alterações registradas na literatura sobre a idade dos genitores, os padrões de uxorilocalidade e de intergeracionalidade no casamento, a composição dos grupos garante a presença de um casal mais velho e, portanto, de ao menos uma oleira pintora experiente, para pintar o corpo de todas e cada uma das crianças.

Os kunumi rukara refletem a importância que os Asuriní atribuem à filiação e à aliança entre siblings em um mesmo grupo, diante de outros, com os quais a socialidade se faz pela oposição. A tendência de diminuição da uxorilocalidade resulta nos agrupamentos de primos patrilaterais, mas o ukara da mãe da mãe nunca é interditado, de forma que os agrupamentos sempre podem ocorrer tanto matri quanto patrilateralmente. Foram observados tanto agrupamentos de tios/sobrinhos e primos matrilineares quanto patrilineares e não identificados diferenciação entre sobrinhos e primos cruzados ou paralelos na composição dos grupos. A única distinção que identificada é que não se agrupavam com sobrinhos e primos matrilineares e patrilineares ao mesmo tempo, caso estes não pertencessem ao mesmo ukara. Fatores como sexo, idade e afinidade influenciam nesta escolha e não há uma clara hierarquia definida pela idade entre as crianças, ainda que os mais velhos assumam papeis de liderança. A rivalidade entre os grupos de crianças de sessões domésticas diferentes, por outro lado, é declarada. Em suma, ego pode ativar alternadamente uma rede de relações com pessoas de sua faixa etária e/ou gênero, dadas matri ou patrilateralmente, as demais, por princípio, estão no registro da afinidade.

Partindo-se deste recorte, pode-se sugerir que se molda um consanguíneo ao mesmo tempo em que se delimita a distância para se garantir um afim. $O$ casal mais velho e o grupo de siblings, de mesmo sexo ou sexo oposto, compõe uma unidade de fabricação da consanguinidade. Já a afinidade se impõe onde a distância é colocada, seja pelo afastamento físico ou pela oposição formal. Sexo e idade, como

MARQUI, Amanda Rodrigues; MIRANDA, Xanda de Biase. Perspectivas etnográficas e infâncias indígenas: modos de ser das crianças Asuriní e Baniwa. Revista da FUNDARTE. Montenegro, p.0128, ano 20, no 42, julho/setembro de 2020.

Disponível em: http://.seer.fundarte.rs.gov.br/index.php/RevistadaFundarte/index> 30 de setembro de 2020 


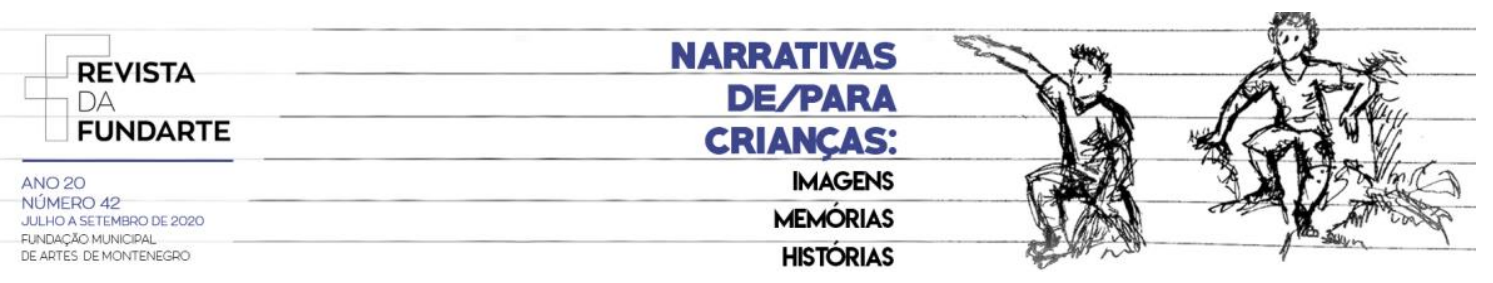

adianta Müller (1990, p.66), são princípios distintivos "que operam conjuntamente nas regras de casamento e estão, portanto, relacionados à formação dos grupos domésticos". No campo do nosso estudo, operavam antes na ativação de relações de consanguinidade e afinidade entre grupos as crianças, dadas, respectivamente, nos espaços de dentro e de fora dos ukara. Aqui, como entre os Galibi-Marworno, se casa com quem não se brinca ${ }^{26}$ (CODONHO, 2007, p.81).

Essas áreas de mobilidade infantil, decerto, refletem os grupos domésticos descritos por Müller (1990, p. 303-308), mas a rigor a criança circula por mais de um. Estendemos o uso termo para abarcar este ponto de vista, próprio da criança, representando relações ativas de convivência e comensalidade. Mas o sentido de ukara está relacionado, sobretudo, ao continente de socialidade onde o corpo é moldado de acordo com as habilidades específicas dos homens e mulheres com quem a criança convive. Cada ukara produz corpos do seu jeito, com seu estilo, como as oleiras de um grupo doméstico produzem vasilhames estilisticamente diferenciados de outros, ainda que dentro dos mesmos padrões técnicos. Toda experiência fora deste recipiente é da ordem da exterioridade e pode interferir no processo. Em síntese, tomando o ukara como metáfora continente, tal como a perpetuação da olaria exige determinadas condições técnicas, dominadas apenas por ceramistas experientes, se dá a concepção de crianças. E o recipiente ideal para a fabricação de corpos belos tem uma composição intergeracional, de gênero e, de preferência, reúne irmãos ou pais e filhos, em casamentos concomitantes, minimizando as tensões dadas pela bilateralidade.

\footnotetext{
${ }^{26}$ Os kunumi rukara apresentam estreitos paralelismos com a morfologia dos hã entre os Galibi-Marworno (ou Galibi do Uaçá). O recorte dado pelos kunumi rukara entre os Asurini talvez fosse ainda mais semelhante aos hã Galibi se feito em um tempo passado em virtude da tendência de diminuição da uxorilocalidade. Se comparada aos Galibi, a rede de relações que pode ser ativada pelas crianças é amplificada por este aspecto bilateral do parentesco. A rivalidade entre os grupos, por outro lado, parece proporcionalmente acentuada.
}

MARQUI, Amanda Rodrigues; MIRANDA, Xanda de Biase. Perspectivas etnográficas e infâncias indígenas: modos de ser das crianças Asuriní e Baniwa. Revista da FUNDARTE. Montenegro, p.0128, ano 20, no 42, julho/setembro de 2020.

Disponível em: http://.seer.fundarte.rs.gov.br/index.php/RevistadaFundarte/index> 30 de setembro de 2020 


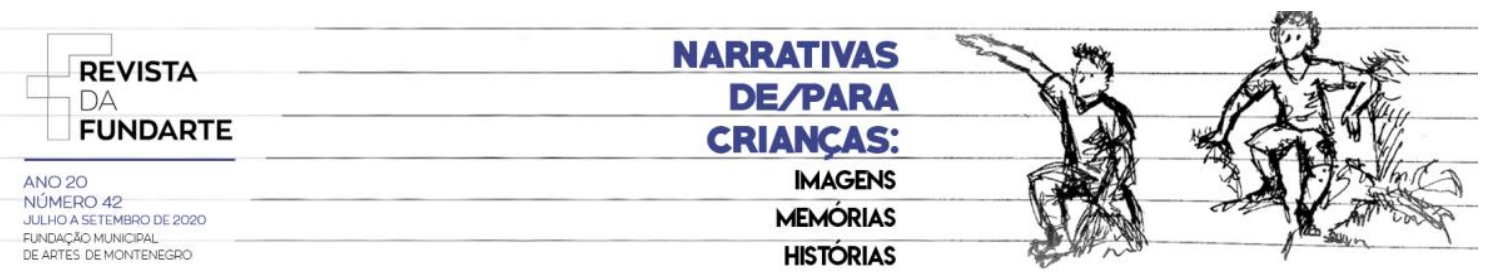

\section{As crianças baniwa}

No dia a dia na comunidade as crianças ficam com seus irmãos ou em grupos de primos agnáticos que residem próximos ${ }^{27}$. Quando as crianças não estão em suas casas, na escola ou jogando bola, permanecem em seus pátios domésticos (pantti pokodee ou pantti nomakoa), com seus primos ou irmãos brincando (patopikataka) ou fazendo alguma atividade. É incomum as crianças estarem sozinhas na comunidade. Em nenhum momento notou-se que crianças de diferentes pátios domésticos brincassem juntas ou, tampouco, que estes espaços fossem usados pelos jovens e adultos para encontros ou conversas casuais. As brincadeiras nos pátios domésticos são futebol, carrinho entre os meninos, que podia ser feito com uma latinha e barbante ou comprados da cidade, e bonecas ou bichos de pelúcia entre as meninas. Nestes espaços as crianças brincam e exibem seus animais de criação $^{28}$, geralmente filhotes de tatu, anta, araras, paca e cotia encontrados por suas mães e pais. As crianças davam comida, apertavam e puxavam os animais, que no seu ponto de vista era um modo de cuidar, embora os filhotes logo viessem a falecer. Era comum também ver breves expedições de meninos com pequenas zarabatanas e flechinhas sem veneno para pegar passarinhos no topo das árvores da comunidade. Suas tentativas geralmente assustavam os pássaros que voavam rapidamente, então os meninos corriam para outras árvores e tentavam novamente. As primeiras tentativas de caçaria pelos meninos são feitas em pares que podem ser entre irmãos ou primos na comunidade.

Algumas etnografias sobre a infância indígena indicam a pertinência na observação da circulação das crianças nos espaços da aldeia (COHN, 2000;

${ }^{27}$ Considerando que modelo de residência no alto rio Negro é a virilocalidade, as comunidades são idealmente formadas por primos agnáticos. Quando um homem se casa é escolhido o local onde será construída a sua nova moradia, geralmente ao lado ou bem próximo à casa dos pais. Nas situações em que uma família se muda para outra comunidade a casa será construída nos espaços novos da comunidade, próxima às famílias que detenham algum tipo de relação de parentesco. E nos poucos casos em que as mulheres permanecem junto com seus familiares, sua casa também será construída próxima da casa dos pais.

${ }_{28}$ Os cachorros da aldeia não tinham muita estima entre as crianças, somente quando havia uma ninhada os filhotes eram motivos de brincadeira e curiosidade. Os gatos são bem menos frequentes nas comunidades baniwa do Médio Içana. Sobre os animais de criação entre povos indígenas cf. Vander Velden (2010).

MARQUI, Amanda Rodrigues; MIRANDA, Xanda de Biase. Perspectivas etnográficas e infâncias indígenas: modos de ser das crianças Asuriní e Baniwa. Revista da FUNDARTE. Montenegro, p.0128, ano 20, no 42, julho/setembro de 2020.

Disponível em: http://.seer.fundarte.rs.gov.br/index.php/RevistadaFundarte/index> 30 de setembro de 2020 


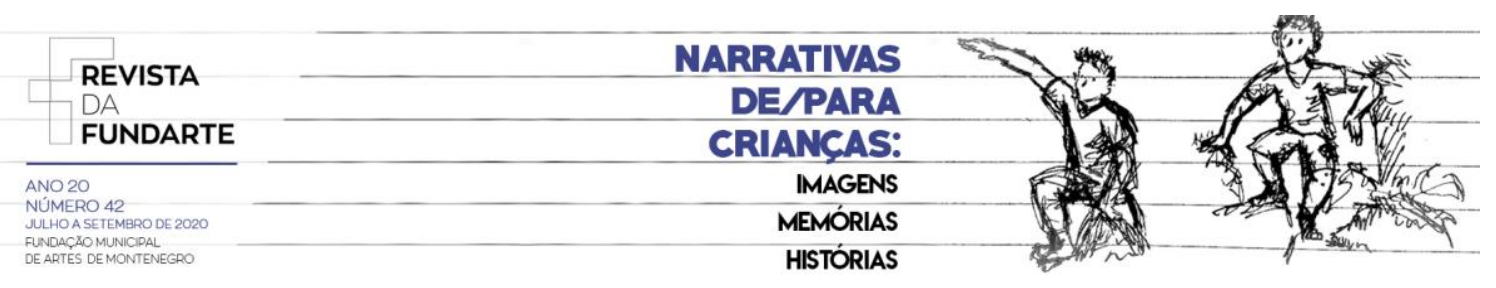

CODONHO, 2007; MANTOVANELLI, 2011; MIRANDA, 2014). A análise de Codonho (2007) será referência à reflexão sobre a circulação das crianças baniwa pelos espaços da comunidade de Vista Alegre. A ideia aqui é demonstrar que as crianças são donas, iminali, de seus pátios domésticos (pantti pokodee ou pantti nomakoa) e que estes locais propiciam experiências de aprendizado sobre o domínio do uso dos diversos espaços da comunidade. Levando em consideração as categorias de hierarquia, ancestralidade e reciprocidade existentes na ocupação tradicional do território baniwa (GARNELO, 2003) e as prerrogativas de ocupação e uso dos espaços na comunidade como, por exemplo, a construção de novas casas, a abertura de novas roças, os caminhos, o porto familiar, entende-se que os pátios domésticos sejam um modo das crianças aprenderem essas noções. De acordo com uma mãe da comunidade, as famílias orientam seus filhos para brincarem somente em seus pátios domésticos e que as crianças são donas de suas brincadeiras, além disso as mães podem observar os comportamentos de seus filhos. Portanto, uma criança de um pátio não irá ao outro para brincar, somente se for chamada - o que, de fato, não acontece- e que aquele espaço é restrito as crianças residentes das casas próximas e ligadas por relações de parentesco (primos agnáticos).

Esta situação também foi notada por Codonho (2007) com as crianças GalibiMarworno e os grupos de convivência, denominados hãs, em que as crianças compartilham brincadeiras e vivências. Existe uma série de regras quanto às relações entre as crianças: aquelas que se brincam e aquelas que se evitam, com quem se brinca não se casa. As vivências das crianças em seus pares são experiências contínuas de ensino e aprendizagem infantis, neste sentido a ideia de transmissão horizontal de conhecimento é utilizada como ponto de partida para compreensão dessas experiências de produção de conhecimento compartilhada entre as crianças por meio dos grupos de convivência, hãs (CODONHO, 2007, p.7274). A pesquisa com as crianças Galibi-Marworno demonstra outros processos de produção de conhecimento para além daqueles em que adultos ou velhos ensinam as crianças, e, assim se desfazer da ideia de que as crianças são tábulas rasas (DURKHEIM, 1978), seres passivos ao processo educacional.

MARQUI, Amanda Rodrigues; MIRANDA, Xanda de Biase. Perspectivas etnográficas e infâncias indígenas: modos de ser das crianças Asuriní e Baniwa. Revista da FUNDARTE. Montenegro, p.0128, ano 20, no 42, julho/setembro de 2020.

Disponível em: http://.seer.fundarte.rs.gov.br/index.php/RevistadaFundarte/index> 30 de setembro de 2020 


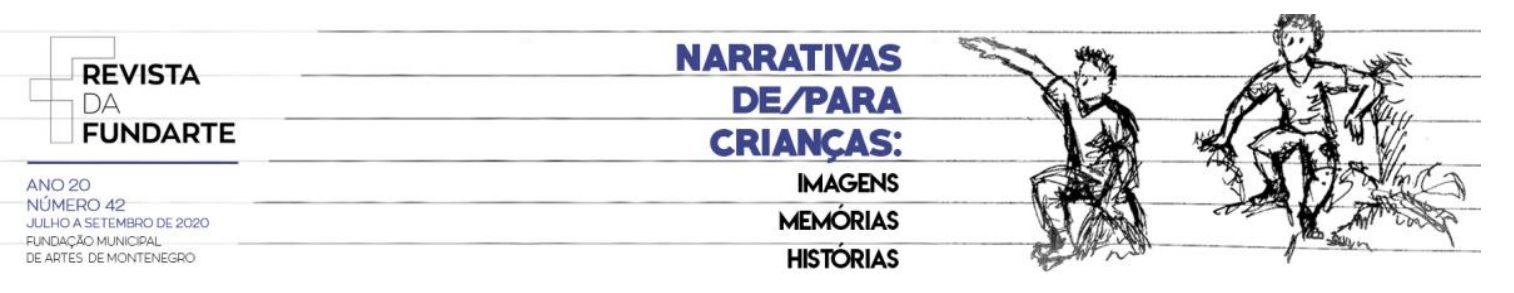

É importante considerar que entre crianças baniwa o grupo de parentesco próximo não prescreve uma restrição matrimonial como foi demonstrado com as crianças Galibi-Marworno (CODONHO, 2007). A regra ideal de casamento entre os Baniwa é com outros clãs-sibs (da mesma fratria), embora nota-se que as alianças matrimoniais não seguem à risca essa regra. Em sua pesquisa na escola Pamáali, Diniz (2011) observou o surgimento de novas formas de relacionamentos entre jovens, especialmente a amizades e namoros decorrentes da convivência escolar e que permitiram a escolha por parte dos jovens de seus futuros cônjuges implicando em alguns conflitos com as suas respectivas famílias. Outra questão interessante na etnografia de Codonho (2007) é a descrição da rivalidade entre as crianças de diferentes grupos ou terreiros, que não foi notado entre as crianças baniwa de Vista Alegre. As crianças de outros pátios domésticos ficam juntas quando jogam bola e nos banhos após a merenda distribuída no centro comunitário e, nestas situações não foi observado nenhum tipo de desentendimento ou brigas infantis.

\section{Considerações finais}

Partindo de dois contextos etnográfico totalmente distintos, este artigo buscou assinalar a importância de um olhar sobre e com as crianças. A observação da mobilidade e da permanência em determinados espaços, destacados especialmente o rio e os pátios domésticos, contribuiu para a apreensão das especificidades nos modos de ser criança indígena e suas interlocuções com outros exemplos no horizonte teórico da antropologia.

Entre as crianças Asuriní, o estímulo à permanência no rio está relacionado ao papel da água na fabricação dos corpos, práticas que combinam a imobilidade temporária durante a aplicação do grafismo, os cordões que modelam membros, a agência do jenipapo, os banhos que reativam e potencializam estes efeitos e, por fim, a visibilidade e o caráter propriamente humano da forma dados pela pintura corporal. Dentre os saberes ontológicos que fundamentam estas práticas, 


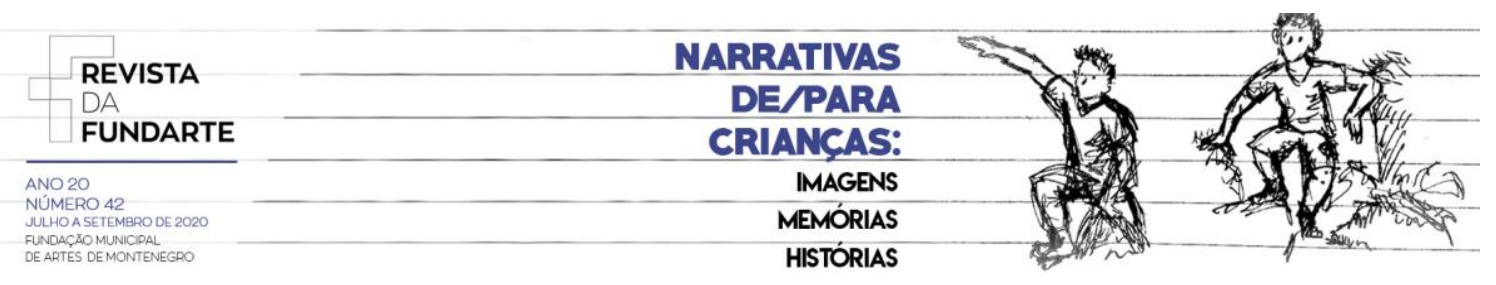

destacamos os de Tauva, sobrenatural das águas, a oleira primordial, a mulher pintora no papel de xamã que maneja a habilidade de moldar belos corpos.

Nas observações sobre as crianças baniwa nas águas buscou delinear aspectos sobre os cuidados com o corpo e a disciplina, partes fundamentais da construção do corpo baniwa e os modos como as crianças significam o uso desses espaços, a partir das brincadeiras e da alimentação feita na beira do rio após a merenda no centro comunitário. Além disso, nota-se que as águas proporcionam inúmeros saberes e técnicas relativas ao gênero e a faixas etárias das crianças baniwa.

Entre os Asuriní, se observam agrupamentos de crianças de mesmo gênero e faixa, tendo por referência os pátios dos grupos domésticos, os kunumi rukara, terreiros de criança. Essas áreas de livre circulação e aliança representam o território de parentesco e comensalidade da criança. Não se frequenta cotidianamente o ukara de outras e onde este encontro e convivência se tornam inevitáveis a socialidade ocorre no registro da afinidade, pela oposição. Esta última configuração, que não ocorria no cenário de baixa densidade populacional e restrição da natalidade dado no pós contato, no qual muitas crianças nem chegavam a socializar com outras crianças, revela um princípio do estruturante do parentesco, a proximidade prescreve restrições ao casamento. De uma perspectiva própria do espaço social infantil, a dinâmica dos kunumi rukara revela a produção e reinvenção da cultura pela criança. Mas não qualquer criança, o kunumi Asuriní.

Em relação a circulação das crianças baniwa, podemos considerar os pátios domésticos, pantti pokkoné, como espaços privilegiados à observação das interações e brincadeiras infantis, que acontecem preferencialmente com os irmãos e primos agnáticos e não prescreve uma restrição matrimonial como descrito em outras etnografias (CODONHO, 2017). Além disso, os pátios domésticos se configuram como um espaço genuinamente infantil, pois segundo as mães das crianças elas são as donas daqueles espaços, neste sentido seria um modo de valorizar o protagonismo infantil e propiciar experiências de aprendizado sobre os diferentes usos dos espaços da comunidade

MARQUI, Amanda Rodrigues; MIRANDA, Xanda de Biase. Perspectivas etnográficas e infâncias indígenas: modos de ser das crianças Asuriní e Baniwa. Revista da FUNDARTE. Montenegro, p.0128, ano 20, ํㅡ 42, julho/setembro de 2020.

Disponível em: http://.seer.fundarte.rs.gov.br/index.php/RevistadaFundarte/index> 30 de setembro de 2020 


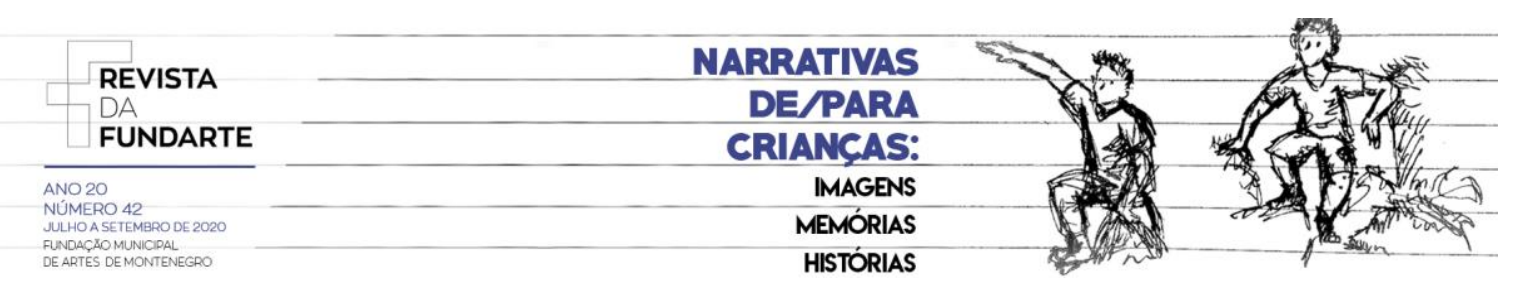

Por fim, as narrativas sobre e com as crianças Asuriní e Baniwa descritas brevemente neste artigo buscaram enfatizar a importância da perspectiva infantil nas etnografias dos povos ameríndios pois consideramos que olhar para a infância permita acessar outros saberes e conhecimentos durante a pesquisa de campo bem como produzir análises inovadoras ao debate antropológico.

\section{Referências:}

CODONHO, C.G. Aprendendo entre pares: a transmissão horizontal de saberes entre as crianças indígenas Galibi-Marworno (Amapá, Brasil). Dissertação de Mestrado. UFSC, 2007.

COHN, C. A criança indígena: a concepção Xikrin de infância e aprendizado. Dissertação de Mestrado. Departamento de Antropologia. São Paulo: Universidade de São Paulo, 2000a.

COHN, C. Noções sociais de infância e desenvolvimento infantil. Cadernos de Campo. São Paulo: PPGAS/USP, vol. 9, n 10.

COHN, C. A experiência da infância e o aprendizado entre os Xikrin. In: LOPES DA SILVA, A.; MACEDO, A.; NUNES, A. Crianças indígenas: ensaios antropológicos. São Paulo: Global, 2002.

COHN, C. A criança, o aprendizado e a socialização na antropologia. In: LOPES DA SILVA, A.; MACEDO, A.; NUNES, A. Crianças indígenas: ensaios antropológicos. São Paulo: Global. 2002b.

COHN, C. Antropologia da Criança. São Paulo: Jorge Zahar, 2005.

$\mathrm{COHN}$, C. Concepções de infância e infâncias: um estado da arte da antropologia da criança no Brasil. Civitas: Revista de Ciências Sociais. Porto Alegre: PUC, vol. 13, n. 2, 2013.

DEMARCHI, A. É a pintura corporal, cultura material? Notas sobre a pintura corporal Mebemgôkre - Kaiapó. In: Reunião de Antropologia Brasileira, Belém, 27, p. 21, 2010.

DINIZ, L. L. Relações e trajetórias sociais dos jovens Baniwa na Escola Pamáali no Médio Rio Içana - Noroeste Amazônico. Dissertação de Mestrado. PPGAS:UFAM. Manaus, 2011.

DURKHEIM, E. A educação, sua natureza e função. In: Educação e Sociologia. São Paulo: Melhoramentos, FNME, 1978. 


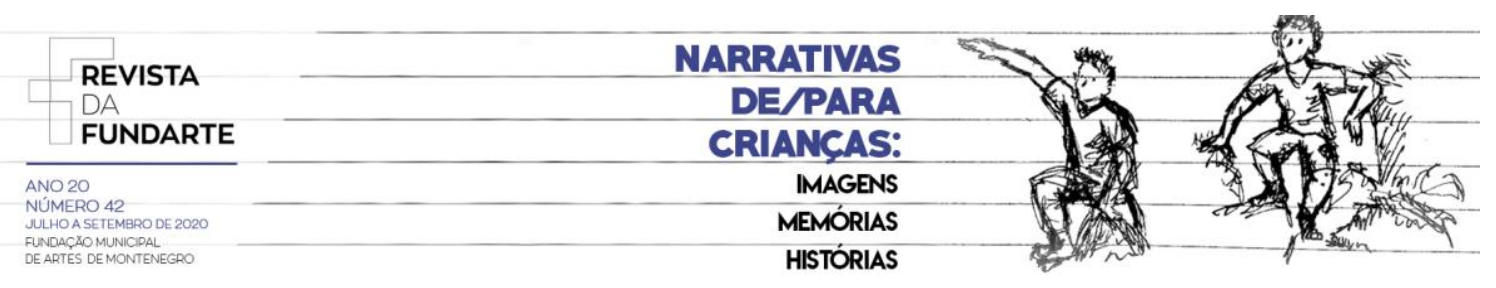

FAUSTO, C. Inimigos fiéis: história, guerra e xamanismo na Amazônia. São Paulo: Edusp, 2001.

GALLOIS, C. J. S. Expressão gráfica e oralidade entre os Wajãpi do Amapá. Rio de Janeiro: Iphan, 2006.

GALLOIS, C. J. S. Sentidos e formas do habitar indígena: entre mobilidade e sedentarizarão. Um estudo de caso entre os Wajãpi do Amapá. Dissertação de mestrado Programa de Pós graduação em Planejamento Urbano e Regional da Universidade Federal do Rio de Janeiro, 2004.

GALLOIS, C. J. S. Arte icnográfica Waiãpi. IN: VIDAL, L. Grafismo Indígena. São Paulo: Nobel/FAPESP/EDUSP, 1992.

GARNELO, L. Poder, Hierarquia e Reciprocidade: saúde e harmonia entre os Baniwa do Alto Rio Negro. Rio de Janeiro: Editora Fiocruz, 2003.

GOW, P. O parentesco como Consciência Humana: o caso dos Piro. In: Mana Estudos de Antropologia Social, 3 (2), p.39-65, 1997.

LOPES DA SILVA, A.; NUNES, A.; MACEDO, A. (orgs). Crianças indígenas: ensaios antropológicos. São Paulo: Global, 2002.

MANTOVANELLI, T. R. Crianças invisíveis da Reserva Indígena Icatu. Dissertação (mestrado). São Carlos, PPGAS/UFSCar, 2011.

MARQUI, A. R. Relações entre infância, escola e religião: etnografia dos Baniwa do Médio Içana. Tese de Doutorado. PPGAS/UFSCar. São Carlos, 2017.

MEAD, M. Growing Up in New Guinea. A Comparative Study of Primitive Education. New York : Perennial Classics, 2001.

MIRANDA, X. B. Kunumi Rukara: terreiros de criança Asuriní. Dissertação (Mestrado). São Carlos, PPGAS/UFSCar, 2014.

MONSERRAT, R. M. F.; IRMÃZINHAS DE JESUS. Língua Asuriní do Xingu. Observações gramaticais. Altamira: Conselho Indigenista Missionário, 1998.

MULLER, S. Além da Civilização (Beyond Civilization). São Paulo: Livraria Independente Editora, 1952.

MÜLLER, R. A. P. Asurini do Xingu. Revista de Antropologia, v. 27, p. 91-114, 1984.

MÜLLER, R. A. P. De Como cincoenta e duas pessoas reproduzem uma sociedade indígena: os Asuriní do Xingu. Tese (Doutorado em Antropologia Social). São Paulo: FFLCH, USP, 1987.

MÜlleR, R. A. P. Os Asuriní do Xingu (História e Arte). Campinas: Editora UNICAMP, 1990.

MARQUI, Amanda Rodrigues; MIRANDA, Xanda de Biase. Perspectivas etnográficas e infâncias indígenas: modos de ser das crianças Asuriní e Baniwa. Revista da FUNDARTE. Montenegro, p.0128, ano 20, ํㅡ 42, julho/setembro de 2020.

Disponível em: http://.seer.fundarte.rs.gov.br/index.php/RevistadaFundarte/index> 30 de setembro de 2020 


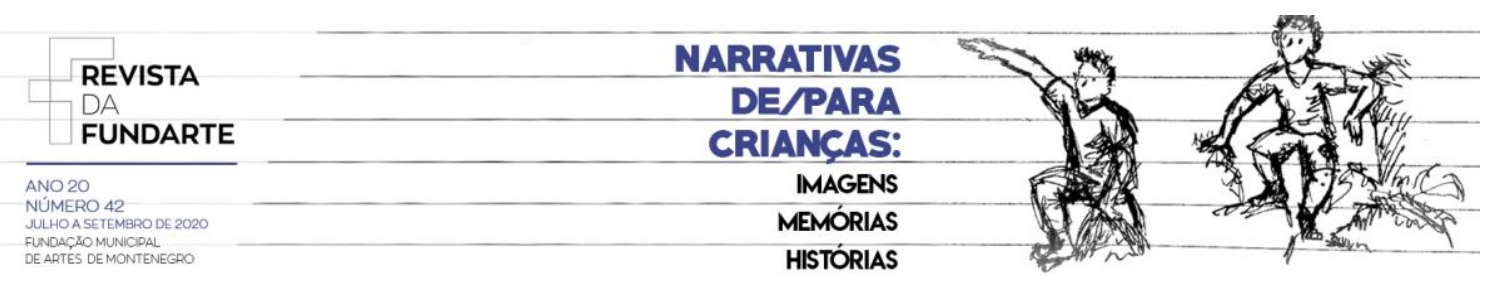

MÜLLER, R. A. P. Tayngava: a noção de representação na arte gráfica. In: VIDAL, L. (Org.). Grafismo Indígena. São Paulo: Studio Nobel/EDUSP/FAPESP, 1992.

MÜLLER, R. A. P. Corpo e imagem em movimento: há uma alma nesse corpo. Revista de Antropologia, v. 43 (2), 2000.

MÜLLER, R. A. P. As crianças no processo de recuperação demográfica dos Asurini do Xingu. In: LOPES DA SILVA, A. SILVA MACEDO, A.L.V. E NUNES, A. (orgs.) Crianças Indígenas: Ensaios Antropológicos. São Paulo: Global, 2002.

MÜLLER, R. A. P. Arte gráfica Asuriní do Xingu:Corpo, mito e pensamento. In: SEVERI, C.; LAGROU, E. (ORGS). Quimeras em diálogo: grafismo e figuração nas artes indígenas. Rio de Janeiro: Letras, 2013.

PEREIRA, R. F. Criando gente no Alto Rio Negro: um olhar waíkhana. Dissertação de Mestrado. PPGAS/UFAM. Manaus, 2013.

RIBEIRO, B. G. (Org.) A oleira e a tecelã. Revista de Antropologia, São Paulo, n.26, p. 25-61, 1982

RIBEIRO, B. G. Tecelãs tupi do Xingu. Revista de Antropologia, 27, 355402.Departamento de Antropologia: USP, 1984.

RIBEIRO, B. G. Suma Etnológica Brasileira. Petrópolis: Vozes/FINEP. v. 1, 1987.

SEEGER, A; DA MATTA, R.; VIVEIROS DE CASTRO, E. B. A construção da Pessoa nas Sociedades Indígenas. Boletim do Museu Nacional. Rio de Janeiro, n. 32, pp.02-19, 1979.

SILVA, A. L.; FERREIRA, M. K. L. (Org.). Antropologia, História e Educação - a questão indígena e a escola. São Paulo: Global; Mari/USP; Fapesp, 2001.

SILVA, F. A. As Tecnologias e seus significados: um estudo etnoarqueológico da cerâmica dos Asurini do Xingu e da cestaria dos Kayapó-Xikrin do Catete. Tese (Doutorado em Antropologia Social). São Paulo, FFLCH, USP, 2000.

SOUZA, M.L.R. Nomes e História do Contato entre os Asurini do Xingu. Dissertação (Mestrado em Antropologia Social). São Paulo: FFLCH, 1994.

VIDAL, L. (org). Morte e vida de uma sociedade indígena brasileira: os KayapóXikrin do rio Catete. São Paulo: Hucitec, Edusp, 1977.

VIDAL, L. Grafismo Indígena. Estudos de antropologia estética. São Paulo: Studio Nobel/ Edusp/ Fapesp, 1992.

VIDAL, L.; LOPES DA SILVA, A. Conclusão. Antropologia estética: enfoques teóricos e contribuições metodológicas. In: VIDAL, L. Grafismo Indígena. Sao Paulo, Nobel/FAPESP/EDUSP, 1992.

VILAÇA, A. Making Kin Out of Others. Journal of the Royal Anthropological Institute, 8(2), 2002.

MARQUI, Amanda Rodrigues; MIRANDA, Xanda de Biase. Perspectivas etnográficas e infâncias indígenas: modos de ser das crianças Asuriní e Baniwa. Revista da FUNDARTE. Montenegro, p.0128, ano 20, no 42, julho/setembro de 2020.

Disponível em: http://.seer.fundarte.rs.gov.br/index.php/RevistadaFundarte/index> 30 de setembro de 2020 


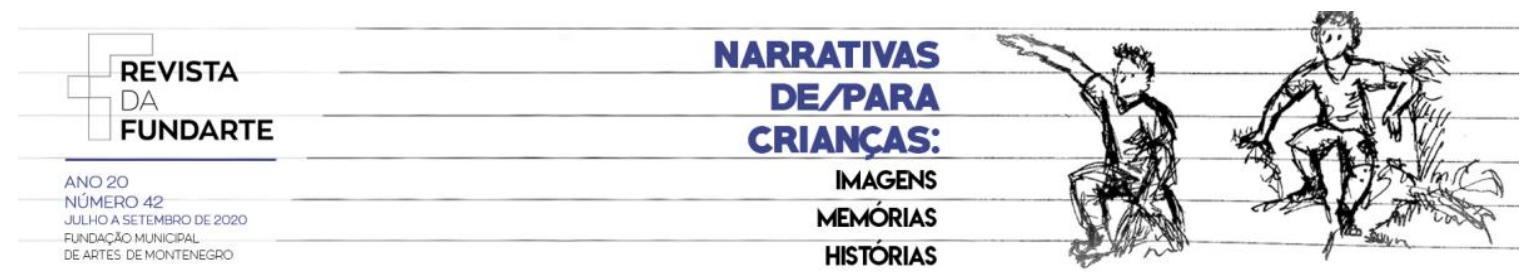

VIVEIROS DE CASTRO, E. Araweté: os deuses canibais. Rio de Janeiro: Jorge Zahar Editor, 1986.

VELDEN, F. F. V. Inquietas companhias. Sobre os animais de criação entre os Karitiana. Tese (Doutorado). Campinas:PPGAS-UNICAMP, 2010.

WRIGHT, R. Pursuing the spirit: semantic construction in Hohodene Kalidzamai chants for initiation. Amerindia, Paris, v.18, p.1-40, 1993.

XAVIER, C. L. Os Koripako do Alto Içana - Etnografia de um grupo indígena evangélico. Tese de Doutorado. Museu Nacional/UFRJ. Rio de Janeiro, 2013.

MARQUI, Amanda Rodrigues; MIRANDA, Xanda de Biase. Perspectivas etnográficas e infâncias indígenas: modos de ser das crianças Asuriní e Baniwa. Revista da FUNDARTE. Montenegro, p.0128, ano 20, no 42, julho/setembro de 2020.

Disponível em: http://.seer.fundarte.rs.gov.br/index.php/RevistadaFundarte/index> 30 de setembro de 2020 